\title{
Soya saponin improves egg-laying performance and immune function of laying hens
}

Peng Li, Yizhu Zhao, Shaojia Yan, Bocheng Song, Yongfa Liu, Mingkun Gao, Dazhi Tang and Yuming Guo* (i)

\begin{abstract}
Background: Soya saponin (SS), an active compound in soybean meals, has been widely studied in the medical field. However, it was considered as an anti-nutritional factor in poultry diets. The objective of this experiment was to measure the effects of dietary SS using three dietary treatments on egg-laying performance and immune function of laying hens. Birds were fed a low soybean meal basal diet (CON), a low-SS diet (50 SS) containing 50 $\mathrm{mg} / \mathrm{kg} \mathrm{SS}$, or a high-SS diet (500 SS) containing $500 \mathrm{mg} / \mathrm{kg} \mathrm{SS}$ for 10 weeks. At the end of the 5 th and 10th week of the trial, samples were collected for analysis.

Results: Results showed that with $50 \mathrm{mg} / \mathrm{kg}$ SS supplementation, the egg production rate, feed conversion ratio (FCR), and eggshell quality tended to be improved. Serum follicle stimulating hormone (FSH) and Interleukin-4 (IL-4) levels were also elevated as well as the peripheral blood LPS stimulation index, the proportion of B lymphocytes, and antibody titer of bovine serum albumin (BSA). We also found that mRNA levels of follicle stimulating hormone receptor (FSHR) in ovarian, nuclear transcription factor kappa B (NF-KB), Transforming growth factor (TGF- $\beta$ ) and interferon $\gamma(I F N-\gamma)$ in spleen were up-regulated at the end of the trial. Additionally, dietary $50 \mathrm{mg} / \mathrm{kg}$ SS improved the ileal flora via up-regulating the relative abundance of Lactobacillus, Romboutsia and Lactobacillus delbrueckii. Although the immune related indicators were improved with $500 \mathrm{mg} / \mathrm{kg}$ SS supplemented, it seemed to have a negative influence on the laying-performance. Specifically, serum alanine aminotransferase (ALT), alkaline phosphatase (ALP), and the ratio of IFN- $\gamma$ to IL-4 were increased in the 500 SS group at the end of the trial. The mRNA levels of gonadotropin releasing hormone $1(G n R H 1)$ in Hypothalamus, the estrogen related receptor (ERR) in ovaries were downregulated as well as the egg production rate during the trial with $500 \mathrm{mg} / \mathrm{kg} \mathrm{SS}$ supplemented.

Conclusions: The egg production performance was improved by dietary supplemented with $50 \mathrm{mg} / \mathrm{kg}$ SS via increasing ovarian FSHR transcription level and serum estrogen level. A beneficial shift in intestinal microflora was recorded, and the immune function of laying hens was also improved with $50 \mathrm{mg} / \mathrm{kg}$ SS supplementation. Surprisingly, the long-term supplementation of $500 \mathrm{mg} / \mathrm{kg}$ SS exerted a negative impact on the laying performance and physiological functions of the liver of laying hens.
\end{abstract}

Keywords: Egg-laying performance, Immune function, Laying hens, Soya saponin

* Correspondence: guoyum@cau.edu.cn

State Key Laboratory of Animal Nutrition, China Agricultural University,

Beijing 100193, China

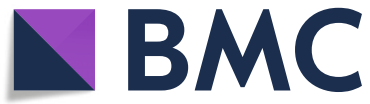

() The Author(s). 2021 Open Access This article is licensed under a Creative Commons Attribution 4.0 International License, which permits use, sharing, adaptation, distribution and reproduction in any medium or format, as long as you give appropriate credit to the original author(s) and the source, provide a link to the Creative Commons licence, and indicate if changes were made. The images or other third party material in this article are included in the article's Creative Commons licence, unless indicated otherwise in a credit line to the material. If material is not included in the article's Creative Commons licence and your intended use is not permitted by statutory regulation or exceeds the permitted use, you will need to obtain permission directly from the copyright holder. To view a copy of this licence, visit http://creativecommons.org/licenses/by/4.0/ The Creative Commons Public Domain Dedication waiver (http://creativecommons.org/publicdomain/zero/1.0/) applies to the data made available in this article, unless otherwise stated in a credit line to the data. 


\section{Introduction}

Soya saponin (SS) is a pentacyclic triterpenoid naturally occurring compound in soybeans. In the past, SS was considered as an anti-nutritional factor in soybean meals for poultry. Nevertheless, it has been widely studied in recent years because of its immunomodulatory effects. SS is composed of soybean sapogen and some glycosides, uronic acid, etc. Due to the difference in glycosides, SS is divided into four different types: A, B, E, DDMP [1].

The major biological roles of SS have been reported to be associated with inhibiting the production of inflammatory factors via regulating toll-like receptor 4 (TLR4)-nuclear factor kappa beta $(N F-\kappa B)$ and phosphatidylinositol 3-kinase (PI3K)-protein kinase B $(P K B)-N F-\kappa B$ pathway $[2,3]$. Likewise, it also reduced the production of inflammatory factors by activating peroxisome proliferatoractivated receptor- $\gamma$ (PPAR- $\gamma)$ [4]. Some findings suggested its role in down-regulating the production of reactive oxygen species (ROS) to relieve oxidative stress via regulating NF-E2-related factor $2(\mathrm{Nrf}$-2)-antioxidant response element $(A R E)$ pathway [5]. SS could also relieve osteoporosis in mice by activating Smads molecules to promote the transcription of runt-related transcription factor $2(\operatorname{Run} x 2)$ and osterix (Osx) genes [6, 7]. A number of studies reported the beneficial effects of SS supplementation to the diets. To illustrate, the antibody titer of Newcastle disease in broiler serum was elevated without affecting the production performance with $5 \mathrm{mg} / \mathrm{kg}$ SS oral treatment [8]. Study also suggested there were no negative effects on its performance, intestinal morphology and organ index with $20 \mathrm{mg} / \mathrm{kg}$ SS supplemented to the diet of mice [9]. Another study suggested that dietary 20 $\mathrm{mg} / \mathrm{kg} \mathrm{SS}$ alleviated 2,4-dinitro fluoro benzene (DNFB)-induced intestinal microflora imbalance in mice [10]. Most of these studies were done in the medical field.

In vitro studies showed that the proliferation of Staphylococcus aureus and Escherichia coli were inhibited by SS $[11,12]$. SS could also alleviate allergic skin reactions in mice via improving the intestinal microflora [10]. Study suggested that the products of SS fermented by Lactobacillus pentosus could alleviate memory impairment in mice [13]. SS has a similar molecular structure to ginsenosides. It was demonstrated that ginsenoside could promoted proliferation of ovarian cells from chicken through PKC activation and up-regulated cyclin gene expression, and alleviated ovaries dysfunction caused by excessive pregnant mare serum gonadotrophin (PMSG) [14-16]. Study also suggested that ginsenosides inhibited the apoptosis of ovarian granulosa cells from mice, and inhibited the secretion of inflammatory factors [17]. We hypothesized that it could be interesting to explore the effect of SS on reproductive system.

To our knowledge, there is almost no research about the influence of SS on poultry, and the study on the interaction between SS and gut microbes is extremely limited. We hypothesized that dietary an appropriate dose of SS might improve laying performance, immune function, and intestinal microflora of laying hens.

\section{Materials and method}

All procedures adapted for the experiment were approved by the Animal Ethics Committee of China Agricultural University, Beijing, China. The animal welfare number was AW92601202-1-1.

\section{Experimental design and animal management}

A total of 270, 21-week-old Hy-line grey layer hens were housed in a conventional cage in a closed house. The cages were arranged in 3 tiers with 5 cages per tier and 3 birds per cage. The common standard diet was fed for 1 week prefeeding period. After the pre-feeding period, 270 22-weekold Hy-line grey hens were randomly divided into three treatment groups according to the principle of uniform egg production rate $(47 \pm 0.02 \%)$ and similar body weight $(1470 \pm 10 \mathrm{~g})$. Control group (basal diet with low soybean meal, the diet formula was showed in Table 1), 50 SS group (Basal diet supplemented with $50 \mathrm{mg} / \mathrm{kg} \mathrm{SS}$ ), $500 \mathrm{SS}$ group (Basal diet supplemented with $500 \mathrm{mg} / \mathrm{kg}$ SS). There were 6 replicates per treatment and 15 birds per replicate. The test SS was purchased from Xi'an Tongze Biotechnology Co., Ltd. (Shaanxi, China; total SS content was $45.1 \%$ ). The experimental diets were fed for 10 weeks. Eggs were collected and weighed once at 16:00 $\mathrm{h}$ every day. The temperature of laying hen room was controlled at $25 \pm 3^{\circ} \mathrm{C}$, besides, $16 \mathrm{~h}$ light: $8 \mathrm{~h}$ dark lighting program was used. Egg quality was measured every 3 weeks while egg production and feed efficiency were calculated every week. At the end of the 5th week, six laying hens with uniform body weight and egg production rate from each group were selected to collect blood from the wing vein, and then to harvest serum and extract lymphocytes for subsequent analyses. At the same time, those birds were anesthetized with $50 \mathrm{mg} / \mathrm{kg} \mathrm{BW}$ of sodium pentobarbital, and then slaughtered to obtain ovaries, fallopian tubes and ileal chyme for further analyses. At the 5th and 7th week of the trial, eight birds from each group were selected for intramuscular injection of $1 \mathrm{~mL}$ of $1 \%$ bovine serum albumin (BSA, Roche 738,328, Switzerland) solution. 7 and 14 days after BSA injection, blood was collected from the wing vein to harvest serum for testing. At the end of the trial, eight birds from each group were selected to collect blood, and then anesthetized and killed to collect ovaries, fallopian tubes, hypothalamus, liver and spleen for further testing.

\section{Determination of production performance and egg quality}

Egg production rate, feed consumption and feed to egg production ratio was calculated. Egg production rate 
Table 1 Test diet composition and nutrition level of air-dry basis

\begin{tabular}{|c|c|c|c|}
\hline Ingredients & Contents, \% & Nutritional parameters ${ }^{c}$ & Levels \\
\hline Corn, $7.8 \%$ pro & 67.55 & $\mathrm{ME}, \mathrm{MC} / \mathrm{kg}$ & 2.701 \\
\hline Dephenolized cottonseed protein, 50\% & 14.00 & Crude protein, $\%$ & 16.530 \\
\hline Limestone powder & 8.154 & Calcium, \% & 3.630 \\
\hline Corn gluten meal, $51.3 \%$ & 5.00 & Total phosphorus, \% & 0.764 \\
\hline Soybean meal, $48 \%$ & 2.00 & Available phosphorus, \% & 0.434 \\
\hline $\mathrm{Ca}\left(\mathrm{HCO}_{3}\right)_{2}$ & 1.86 & Methionine + Cystine, \% & 0.681 \\
\hline $\mathrm{NaCl}$ & 0.35 & Lysine, \% & 0.791 \\
\hline Trace minerals ${ }^{b}$ & 0.30 & Methionine, \% & 0.408 \\
\hline L-Lysine $\mathrm{HCl}, 78 \%$ & 0.25 & Threonine, \% & 0.576 \\
\hline DL-Methionine & 0.12 & Tryptophan, \% & 0.164 \\
\hline Choline chloride, 50\% & 0.12 & Digestible Lysine, \% & 0.725 \\
\hline Tryptophan & 0.02 & Digestible Methionine, \% & 0.386 \\
\hline Multi-vitamins ${ }^{a}$ & 0.03 & Digestible Threonine, \% & 0.505 \\
\hline Sandaquin & 0.03 & Digestible Tryptophan, \% & 0.148 \\
\hline Phytase & 0.016 & & \\
\hline Zeolite powder & 0.2 & & \\
\hline Total & 100 & & \\
\hline
\end{tabular}

The diet was formulated with reference to NY /T33-2004. The content of SS in our SS additives was 45.1\%, and the actual measured values of SS in each group of diets are as follows. The content of SS in the diet of the control group was $9.5 \mathrm{mg} / \mathrm{kg}$. The contents of SS in the 50 SS and 500 SS groups were 31.3 and $275.7 \mathrm{mg} /$ $\mathrm{kg}$, respectively. ${ }^{a}$ Vitamin premix (provided per kilogram of feed) the following substances: vitamin $\mathrm{A}, 12,500 \mathrm{IU}$; vitamin $\mathrm{D}_{3}, 2500 \mathrm{IU}$; vitamin $\mathrm{K}_{3}, 2.65 \mathrm{mg}$; vitamin $\mathrm{B}_{1}, 2 \mathrm{mg}$; vitamin $\mathrm{B}_{2}, 6 \mathrm{mg}$; vitamin $\mathrm{B}_{12}$, $0.025 \mathrm{mg}$; vitamin $\mathrm{E}, 30 \mathrm{lU}$; biotin, $0.0325 \mathrm{mg}$; folic acid, $1.25 \mathrm{mg}$; pantothenic acid, $12 \mathrm{mg}$; niacin, $50 \mathrm{mg}$. ${ }^{\mathrm{b}}$ Trace element premix (provided per kilogram of feed) the following substances: copper, $8 \mathrm{mg}$; zinc, $75 \mathrm{mg}$; iron, $80 \mathrm{mg}$; manganese, $100 \mathrm{mg}$; selenium, $0.15 \mathrm{mg}$; iodine, $0.35 \mathrm{mg}$. 'Calculated value based on the analysis of experimental diets

$(\%)=$ total number of eggs laid during the statistical period / (number of housed hens $\times$ number of statistical days) $\times 100 \%$. Average egg production rate during the test period $(\%)=$ total number of eggs laid during the test period / (number of hens housed $\times$ total days of the test $\times 100 \%$. Feed-to-egg ratio $(\mathrm{FCR})=$ total material consumption during the test / total egg weight during the test.

All eggs from each treatment within $24 \mathrm{~h}$ were collected to measure eggshell thickness, eggshell strength, haugh units, albumen height and egg yolk color. The egg quality tester DET-6000 (NABEL Co., Ltd., Japan) was used to measure the eggshell strength $\left(\mathrm{kg} / \mathrm{cm}^{2}\right)$ and egg yolk color after weighing the eggs. Briefly, the eggs were placed vertically on the eggshell strength tester, with the blunt end up, to measure the pressure on the eggshell surface per unit area. Albumen height was determined with the albumen height measuring instrument KIYA-818B (SEISAKUSHO, LTD), and then the Haugh unit was calculated according to the formula: Haugh Unit $=100 \lg (\mathrm{H}-1.7$ $\left.\mathrm{W}^{0.37}+7.57\right)$, where $\mathrm{H}=$ the albumen height $(\mathrm{mm})$ and $\mathrm{W}=$ the egg weight $(\mathrm{g})$. The thickness of the eggshell was measured with a micrometer. Specifically, after removing the shell membrane from the eggshell, the shell thickness of the blunt end, the middle and the sharp end of the egg were measured to calculate the average of the three. The average value was in millimeters, accurate to $0.01 \mathrm{~mm}$.

\section{Organ index and liver morphology}

The ovaries, oviducts, liver and spleen were weighted with an electronic balance (accurate $0.01 \mathrm{~g}$ ). A ruler (accurate $0.01 \mathrm{~mm}$ ) was used to measure the length of ovary, the total length of the oviduct, the length of the magnum and the shell gland. At the end of the trial, liver tissue samples about $1 \mathrm{~cm}^{2}$ were collected and then suspend it into $4 \%$ paraformaldehyde solution. Liver sections were made and then stained with eosinhematoxylin (HE stain). The Olymps BX-41TF microscope was used to observe the infiltration state of inflammatory cells in liver slices. The magnification was 400 times.

\section{Determination of serum hormone levels, immune indexes and biochemical indexes}

Blood was collected from the wing vein, and then serum was harvested by centrifugation at $3000 \mathrm{rpm}$ and $4{ }^{\circ} \mathrm{C}$ for $15 \mathrm{~min}$. The contents of Follicle stimulating hormone (FSH), Luteinizing hormone (LH), Estradiol (E2) and Progesterone (P4) in serum were detected by radioimmunoassay using commercial kit (from Beijing Northern Biotechnology Institute, Beijing, China). The detection coefficient of variation was less than $10 \%$. The levels of immunoglobulin G, immunoglobulin A and immunoglobulin $\mathrm{M}$ in the serum was detected according to 
the manufacturer's guidelines of Elisa kits (Beijing Solarbio Biotechnology Co., Ltd., China). ELISA kits (IDEXX laboratories lnc., Weatbrook, Maine, USA) were used to determine the levels of interleukin-2 (IL-2), IL-6, IL-4 and interferon- $\gamma$ (IFN- $\gamma$ ) in the serum at the end of 5th and 10th week. The ratio of IFN- $\gamma$ to IL-4 was also calculated. Following the manufacturer's guidelines (Nanjing Jian cheng Biotechnology Co., Ltd., China), an automatic biochemical analyzer (Unicel DXC800, Beckman Coulter, USA) was used to analyze the levels of total serum protein (TP), albumin (ALB), alanine aminotransferase (ALT), aspartate aminotransferase (AST), alkaline phosphatase (ALP) and glucose (GLU) at the end of the trial.

\section{Determination of serum BSA antibody titer}

According to the previous [18], the indirect ELISA method was used to measure the anti-BSA antibody titer in the serum. Briefly, BSA at a concentration of $2 \mathrm{mg} /$ $\mathrm{mL}$ was used to coat 96-well plates and incubated overnight at $4{ }^{\circ} \mathrm{C}$. Subsequently, $0.01 \mathrm{~mol} / \mathrm{L}$ PBS-Tween $(\mathrm{pH}$ $7.4,0.05 \%$ Tween 20) was used to wash the 96-well plate for 5 times, and the serum samples were added to the washed 96-well plate and incubated at $37^{\circ} \mathrm{C}$ for $1.5 \mathrm{~h}$. Peroxidase-labeled chicken polyclonal IgG antibody (Bethyl L aboratories, Inc. US.) was added to the washed 96-well plate to specifically bind to BSA. After that, $100 \mu \mathrm{L}$ of secondary antibody was added to the washed 96-well plate and incubated at $37^{\circ} \mathrm{C}$ for $30 \mathrm{~min}$. After

Table 2 List of gene primer sequences ${ }^{a}$

\begin{tabular}{|c|c|c|c|}
\hline \multirow{2}{*}{$\begin{array}{l}\text { Gene name } \\
G n R H 1\end{array}$} & \multicolumn{2}{|c|}{ Prime sequence(5' to $\left.3^{\prime}\right)$} & \multirow{2}{*}{$\begin{array}{l}\text { Product size, bp } \\
202\end{array}$} \\
\hline & $\mathrm{F}$ & GGCTCAACACTGGTCTTATGG & \\
\hline & $\mathrm{R}$ & TCTTCTGGCTTCTCCTTCG & \\
\hline \multirow[t]{2}{*}{ ERR } & $\mathrm{F}$ & GTACGGCTCTACTACACTCAGTTATGC & 160 \\
\hline & $\mathrm{R}$ & CTGCTGGCTGTGGTGATGGATG & \\
\hline \multirow[t]{2}{*}{$P G R$} & $\mathrm{~F}$ & GTGTCGCTTGAGGAAGTGCTGTC & 116 \\
\hline & $\mathrm{R}$ & CGGCTGGCTGCTGAAGTGC & \\
\hline \multirow[t]{2}{*}{$L H R$} & $\mathrm{~F}$ & CGTCCTCATAACCAGCCACTACAAG & 119 \\
\hline & $\mathrm{R}$ & TCTGAGCATCCACCGAAGCAATG & \\
\hline \multirow[t]{2}{*}{ FSHR } & $\mathrm{F}$ & GTCTCACCTGCTTGCTGATTCTCC & 99 \\
\hline & $\mathrm{R}$ & CCTTGATCTCCTGGCAGATGAATATCC & \\
\hline \multirow[t]{2}{*}{ PPAR- $\gamma$} & $\mathrm{F}$ & TCCTTCCCGCTGACCAAA & 212 \\
\hline & $\mathrm{R}$ & TCCTGCACTGCCTCCACA & \\
\hline \multirow[t]{2}{*}{ TNF-a } & $\mathrm{F}$ & GAGCGTTGACTTGGCTGTC & 64 \\
\hline & $\mathrm{R}$ & AAGCAACAACCAGCTATGCAC & \\
\hline \multirow[t]{2}{*}{$I L-1 \beta$} & $\mathrm{F}$ & ACTGGGCATCAAGGGCTA & 131 \\
\hline & $\mathrm{R}$ & GGTAGAAGATGAAGCGGGTC & \\
\hline \multirow[t]{2}{*}{ IFN- $\gamma$} & $\mathrm{F}$ & AGCTGACGGTGGACCTATTATT & 259 \\
\hline & $\mathrm{R}$ & GGCTITGCGCTGGATTC & \\
\hline \multirow[t]{2}{*}{ IL-4 } & $\mathrm{F}$ & AGACAAATAACAAAACTGAGC & 212 \\
\hline & $\mathrm{R}$ & TTGGTGGAAGAAGGTACG & \\
\hline \multirow[t]{2}{*}{$N F-K B$} & $\mathrm{~F}$ & GTGTGAAGAAACGGGAACTG & 203 \\
\hline & $\mathrm{R}$ & GGCACGGTTGTCATAGATGG & \\
\hline \multirow[t]{2}{*}{ Caspase1 } & $\mathrm{F}$ & CGGCCAGCGCCATCTTCATT & 347 \\
\hline & $\mathrm{R}$ & AGGGAGCTGTCACAGTGCGT & \\
\hline \multirow[t]{2}{*}{$\mathbb{L L}-12$} & $\mathrm{~F}$ & AAGGTGCAGAAGCAGAGGAC & 88 \\
\hline & $\mathrm{R}$ & TTGTGTTGCTCTGACTGTTGG & \\
\hline \multirow[t]{2}{*}{ TGF- $\beta$} & $\mathrm{F}$ & TCATCACCAGGACAGCGTTA & 109 \\
\hline & $\mathrm{R}$ & TGTGATGGAGCCATTCATGT & \\
\hline \multirow[t]{2}{*}{$\beta$-actin } & $\mathrm{F}$ & GAGAAATTGTGCGTGACATCA & 152 \\
\hline & $\mathrm{R}$ & CCTGAACCTCTCATTGCCA & \\
\hline
\end{tabular}


washing, $100 \mu \mathrm{L}$ of $0.05 \%$ tetramethyl acridine was added to the reaction well, incubated at room temperature in the dark for $30 \mathrm{~min}$, and finally terminated with $2 \mathrm{~mol} / \mathrm{L}$ sulfuric acid. An automatic microplate reader (SepctraMax i3x Platform, Molecular Devices, LLC, Australia) was used to read the absorbance value.

\section{Peripheral blood lymphocyte ratio and stimulation index}

According to the method of Fan et al. [19], heparinized blood from the wing vein were diluted with sterile calcium- and magnesium-free Hank's balanced salt solution (CMF-HBSS, Sigma, St. Louis, MO, USA) at a 1:1 ratio and placed on ice. The diluted samples were carefully transferred into a tube added with an equal volume of Ficoll lymphocyte separation medium (Histopague-1077, Tianjin HaoYang Biological Manufacture Co., Ltd., China) to form a distinct layer above the Ficoll. The mixture was centrifuged at $400 \times g$ for $30 \mathrm{~min}$ at room temperature. The centrifuged mixture was divided into three layers, and the white flocculent material in the middle was transferred into a clean tube. The RPMI 1640 (Invitrogen Corp., Grand Island, NY, USA) incomplete culture medium was used to wash the lymphocyte suspension for 3 times, and then the lymphocyte was resuspended into $2 \mathrm{~mL}$ of RPMI 1640 complete culture medium. The cell counter was used to make sure the live cell concentration as $1 \times 10^{7} \mathrm{cell} / \mathrm{mL}$.

The following primary monoclonal antibodies were diluted in PBS (pH 7.2): IgG1א mouse anti-chicken-Bu-1PB-labelled antibody (8395-26), IgG1א mouse antichicken-Monocyte/Macrophage-PE-labelled antibody (8420-09), IgG1k mouse anti-chicken-CD3-APC-labelled antibody (8200-11), and IgG1א mouse anti-chickenCD45-PE- labelled antibody (8270-09) (Southern Biotechnology Associates Inc., Birmingham, AL, USA). A 1-mL eppendorf tube was stained with $25 \mu \mathrm{L}$ of diluted primary monoclonal antibody (1:100 dilution) and the negative isotype control IgG, and then a volume of $100 \mu \mathrm{L}$ of lymphocytes extracted above $\left(2 \times 10^{6}\right.$ cells $)$ was added into this tube for incubation about $45 \mathrm{~min}$ at room temperature. After that, the cold PBS was used to wash the cells twice for removing the unbound primary antibodies. A total of $300 \mu \mathrm{L}$ of hemolysin solution diluted in PBS (1:25) was added to each tube. Finally, the cells were washed twice and adjusted to a final volume of $500 \mu \mathrm{L}$. Four-color flow cytometric analysis was conducted using a Navios EX flow cytometer with 10 colors (Beckman Coulter Corp., Fullerton, CA, USA) at Xi-Yuan Traditional Chinese Medicine Hospital, Chinese Academy of Medicine Science, China. The percentages of $\mathrm{CD}^{+} \mathrm{T}$ cells, Monocytes/
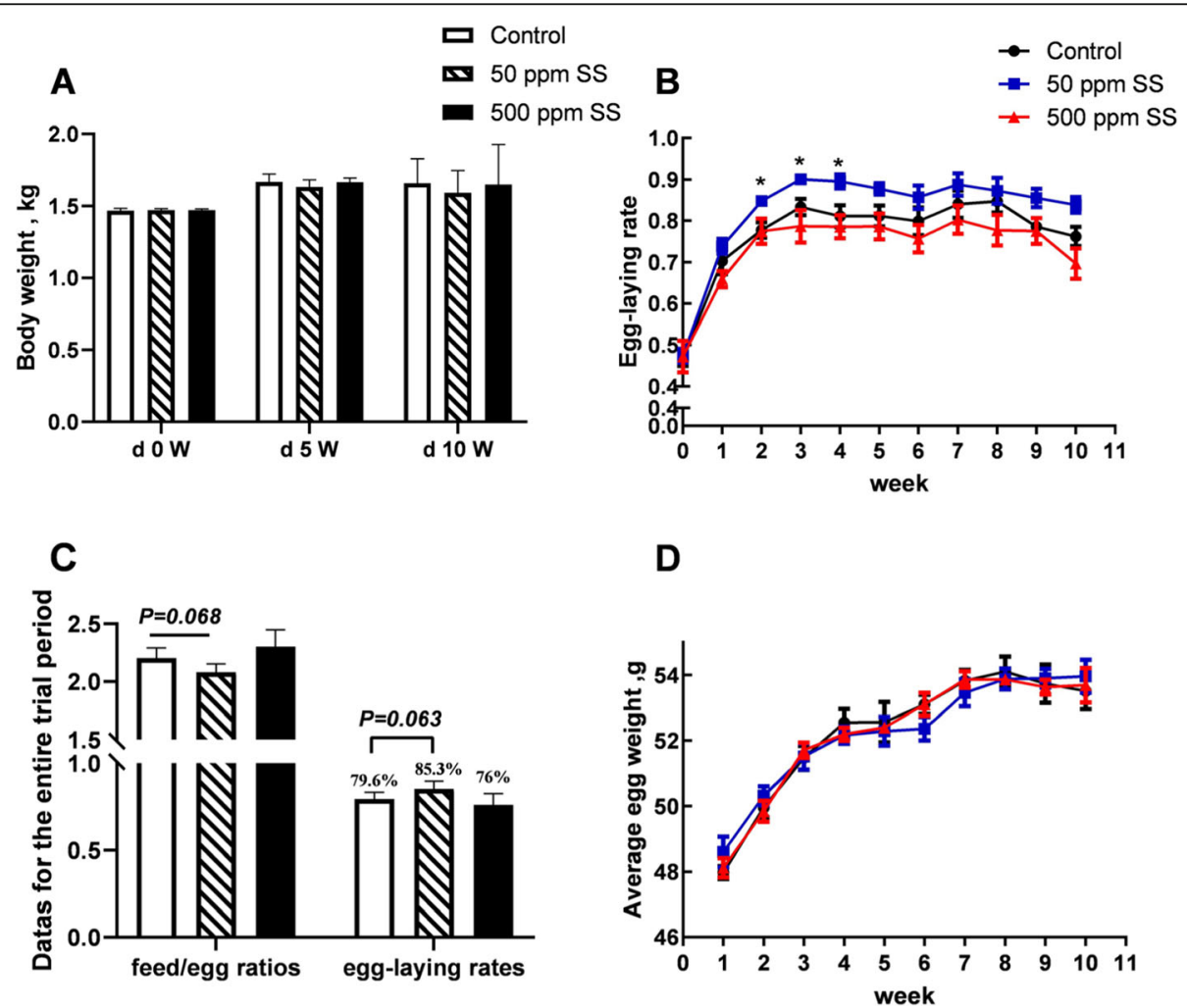

Fig. 1 The effects of SS on laying rate and body weight of laying hens. The above A, B, C, and $\mathbf{D}$ represented the results of body weight, egg production rate, average egg production rate, the ratio of feed to egg (FCR), and average egg weight during the experiment. Among them, * was judged as a significant difference $(0.01<P<0.05)$, the same below, $(n=6)$ 
Table 3 Organs weight index

\begin{tabular}{llllll}
\hline Time & Items & Control & 50 ppm SS & 500 ppm SS & P-value \\
\hline 5th week(27 weeks old, $n=6)$ & Liver, \% & $2.75 \pm 0.44^{\mathrm{b}}$ & $2.25 \pm 0.44^{\mathrm{b}}$ & $2.12 \pm 0.20^{\mathrm{a}}$ & 0.029 \\
& Spleen, \% & $0.13 \pm 0.02$ & $0.12 \pm 0.01$ & $0.12 \pm 0.02$ & 0.482 \\
& Ovaries, \% & $2.69 \pm 0.43$ & $2.90 \pm 0.51$ & $2.78 \pm 0.63$ & 0.791 \\
& Oviducts, \% & $2.41 \pm 1.28$ & $3.43 \pm 0.31$ & $2.90 \pm 0.97$ & 0.208 \\
10th week(32 weeks old, $n=8)$ & Liver, \% & $2.40 \pm 0.42$ & $2.25 \pm 0.22$ & $0.22 \pm 0.52$ & $0.09 \pm 0.01$ \\
& Spleen, \% & $0.09 \pm 0.02$ & $0.10 \pm 0.01$ & $2.20 \pm 0.67^{\mathrm{a}}$ & 0.017 \\
& Ovaries, \% & $2.39 \pm 0.69^{\mathrm{a}}$ & $3.20 \pm 0.64^{\mathrm{b}}$ & $2.99 \pm 1.13$ \\
\hline
\end{tabular}

At the end of the 5th and 10th week of the trial, 6-8 birds from each treatment were selected for slaughter to obtain liver, spleen, oviducts, and ovaries. The calculation formula for the weight index of these tissues is as follows: the organ weight, $\mathrm{g} /$ live weight of birds, $\mathrm{g} \times 100 \%$. The data in Table 3 different superscript letters indicate significant difference $(P<0.05)$; same superscript letters indicate no difference $(P>0.1)$, the same below

Macrophages, and $\mathrm{Bu}-1$ were subsequently calculated. The result was expressed as a percentage.

A 3-(4,5-dimethylthiazol)-2,5-diphenyltetrazolium bromide (MTT, Sigma Chemical Co., St. Louis, MO, USA) method was used to determine the peripheral blood lymphocyte proliferation response [20]. The stimulus index of concanavalin A (Con A, $45 \mu \mathrm{g} / \mathrm{mL}$ ) on $\mathrm{T}$ cells and lipopolysaccharide (LPS, $25 \mu \mathrm{g} / \mathrm{mL}$ ) on B cells were analyzed. The results were expressed in terms of the stimulus index (SI) value. Both Con A and LPS were purchased from Sigma-Aldrich.

\section{Gene expression measurement and analysis}

Hypothalamus, ovarian, liver, and spleen samples were collected and placed in RNase-free Centrifuge tube, and then the samples were quickly placed in liquid nitrogen. Taking $100 \mathrm{mg}$ tissue sample into 1-mL Trizol (Invitrogen Life Technologies, Carlsbad, CA, USA), Total RNA isolation, quantification, cDNA synthesis, and real-time PCR were carried out as previously described by Zhao et al. [21]. Total RNA was quantified by using the NanoDrop ${ }^{\circ}$ ND-2000 UVVIS spectrophotometer (Thermo Scientific, Wilmington, DE, USA) at an OD of $260 \mathrm{~nm}$, and the purity was assessed by determining the OD260/OD280 ratio. All the samples had an OD260/OD280 ratio above 1.8, corresponding to 90$100 \%$ pure nucleic acids. Meanwhile, the integrity of RNA in each sample was assessed using 1\% denatured agarose gel electrophoresis. RNA was used for RT-PCR analysis when it had a $28 \mathrm{~S} / 18 \mathrm{~S}$ rRNA ratio $\geq 1.8$. Total RNA was reversetranscribed using the PrimeScript ${ }^{\ominus}$ RT reagent Kit with gDNA Eraser (Takara, Dalian, China) according to the manufacturer's instruction. cDNA was synthesized and stored at $-80^{\circ} \mathrm{C}$ until use. The RT-PCR analysis of gene expression was performed using primers listed in Table 2, and the SYBR $^{\odot}$ Premix Ex TaqTM (Takara, Dalian, China) on an Applied Biosystems 7500 Fast Real-Time PCR System (Foster City, CA, USA). The total volume of the PCR reaction system was $20 \mu \mathrm{L}$. Amplification products were verified by melting curves, agarose gel electrophoresis, and direct sequencing. Results were analyzed by the cycle threshold (CT) method from Fu et al. [22].

\section{Microbial sequencing and analysis}

The chyme in the distal region of the ileum was collected at end of 5th week. Sequencing and analysis according to the

Table 4 Results of the oviduct section length

\begin{tabular}{|c|c|c|c|c|}
\hline \multirow[b]{2}{*}{ Time } & \multirow[b]{2}{*}{ Group } & \multicolumn{3}{|c|}{ The length of the oviducts, $\mathrm{cm}$} \\
\hline & & Total length & Magnum & Shell gland \\
\hline \multirow[t]{4}{*}{ 5th week(27 weeks old, $n=6$ ) } & Control & $47.98 \pm 18.78$ & $22.45 \pm 13.25$ & $4.67 \pm 1.43$ \\
\hline & 50 ppm SS & $58.33 \pm 6.18$ & $33.64 \pm 4.40$ & $5.87 \pm 1.06$ \\
\hline & 500 ppm SS & $51.73 \pm 11.75$ & $27.80 \pm 7.36$ & $5.45 \pm 1.34$ \\
\hline & $P$-value & 0.414 & 0.138 & 0.291 \\
\hline \multirow[t]{4}{*}{ 10th week(32 weeks old, $n=8$ ) } & Control & $54.07 \pm 4.16$ & $26.34 \pm 6.52$ & $7.32 \pm 0.23^{a b}$ \\
\hline & 50 ppm SS & $58.40 \pm 5.21$ & $32.01 \pm 3.58$ & $8.00 \pm 0.49^{b}$ \\
\hline & 500 ppm SS & $53.88 \pm 14.52$ & $29.25 \pm 8.14$ & $6.69 \pm 1.30^{\mathrm{a}}$ \\
\hline & $P$-value & 0.55 & 0.228 & 0.015 \\
\hline
\end{tabular}

At the end of the 5th and 10th week of the trial, 6-8 birds from each treatment were selected for slaughter to obtain oviducts, and the total length of oviducts, magnum, and shell gland were measured. The data in Table 4 different superscript letters indicate significant difference $(P<0.05)$; same superscript letters indicate no difference $(P>0.1)$, the same below 
Table 5 Egg quality results $(n=11)$

\begin{tabular}{|c|c|c|c|c|c|c|}
\hline Time, week & Group & $\begin{array}{l}\text { Eggshell strength, } \\
\mathrm{kg} / \mathrm{cm}^{2}\end{array}$ & $\begin{array}{l}\text { Albumen } \\
\text { hight, } \mathrm{mm}\end{array}$ & Haugh unit & $\begin{array}{l}\text { Egg yolk } \\
\text { color }\end{array}$ & $\begin{array}{l}\text { Eggshell thickness, } \\
\mathrm{mm}\end{array}$ \\
\hline \multirow[t]{4}{*}{ 1st-3rd (23-25 weeks old) } & Control & $4.27 \pm 0.28^{a}$ & $8.93 \pm 1.00$ & $94.61 \pm 5.82$ & $7.85 \pm 0.42$ & $0.351 \pm 0.015^{a}$ \\
\hline & 50 ppm SS & $4.50 \pm 0.28^{\mathrm{ab}}$ & $9.05 \pm 1.71$ & $93.51 \pm 8.61$ & $7.73 \pm 0.36$ & $0.349 \pm 0.016^{a}$ \\
\hline & 500 ppm SS & $4.73 \pm 0.33^{b}$ & $9.16 \pm 1.45$ & $97.37 \pm 6.42$ & $7.82 \pm 0.34$ & $0.364 \pm 0.007^{b}$ \\
\hline & $P$-value & 0.004 & 0.931 & 0.428 & 0.744 & 0.026 \\
\hline \multirow{4}{*}{$\begin{array}{l}\text { 4th-6th } \\
\text { (26-28 weeks old) }\end{array}$} & Control & $4.53 \pm 0.18$ & $8.21 \pm 1.48^{\mathrm{ab}}$ & $90.85 \pm 8.29$ & $7.48 \pm 0.28$ & $0.366 \pm 0.010^{a}$ \\
\hline & 50 ppm SS & $4.73 \pm 0.53$ & $8.72 \pm 0.49^{b}$ & $92.59 \pm 3.98$ & $7.67 \pm 0.37$ & $0.375 \pm 0.009^{b}$ \\
\hline & 500 ppm SS & $4.52 \pm 0.10$ & $7.38 \pm 0.89^{\mathrm{a}}$ & $88.49 \pm 6.50$ & $7.73 \pm 0.25$ & $0.365 \pm 0.008^{\mathrm{a}}$ \\
\hline & $P$-value & 0.263 & 0.017 & 0.345 & 0.161 & 0.03 \\
\hline \multirow{4}{*}{$\begin{array}{l}\text { 7th-9th } \\
\text { (29-31 weeks old) }\end{array}$} & Control & $4.47 \pm 0.47^{\mathrm{a}}$ & $8.85 \pm 0.71$ & $94.31 \pm 5.57$ & $7.21 \pm 0.40$ & $0.363 \pm 0.015^{a}$ \\
\hline & 50 ppm SS & $4.94 \pm 0.48^{b}$ & $8.90 \pm 0.73$ & $94.37 \pm 4.02$ & $7.31 \pm 0.27$ & $0.378 \pm 0.013^{b}$ \\
\hline & 500 ppm SS & $4.24 \pm 0.42^{a}$ & $9.35 \pm 1.14$ & $97.20 \pm 4.31$ & $7.09 \pm 0.37$ & $0.359 \pm 0.009^{a}$ \\
\hline & $P$-value & 0.004 & 0.362 & 0.271 & 0.346 & 0.003 \\
\hline
\end{tabular}

During the trial, a repeat group was randomly selected from each treatment every 3 weeks, and all the eggs in this repeat group were collected for egg quality determination. The data in Table 5 different superscript letters indicate significant difference $(P<0.05)$; same superscript letters indicate no difference $(P>0.1)$, the same below

method described by Zhang et al. [23]. The method was briefly described as that fecal microbial DNA extraction kit (QIAamp Fast DNA Stool Mini Kit, Qiagen Company, Germany) was used to extract microbial DNA from ileal chyme. Nano Drop 2000 (Thermo Scientific, Waltham, MA, USA) was used to determine the concentration of DNA samples, after which $1 \%$ agarose gel electrophoresis was used to detect the purity of DNA samples. 16SrDNA gene V3-V4 region universal primers $338 \mathrm{~F}$ ( $5^{\prime}$-ACTCCTACGGGAGGCA GCA-3') and 806 R (5'-GGACTACHVGGGTWTCTAAT$\left.3^{\prime}\right)$ were used to amplify bacterial DNA, and then the PCR products were purified, quantified and homogenized to form a sequencing library. HiSeq2500 PE250 was used for on-machine sequencing. Sequencing analysis was completed by Beijing Nuohe Zhiyuan BioInformation Technology Co., Ltd. Qiime software
(Qiime2-2019.7, Nature Biotechnology) was used to generate species abundance tables of different taxonomic levels. The alpha diversity and the beta diversity of the samples were analyzed, and then the UPGMA clustering tree was constructed. Subsequently, LEfSe analysis was performed to find biomarkers with statistical differences between the groups based on the LDA value. $\mathrm{R}$ software (Version 2.15.3) was used to draw Venn diagram, principal coordinate analysis (P CoA) diagram.

\section{Statistical analysis}

Data were presented as means \pm SD and analyzed using one-way ANOVA. Differences among treatment means were determined by Duncan's post hoc test. Pearson correlation analysis was used to analyze the correlation

Table 6 Serum E2, P, LH, FSH levels

\begin{tabular}{|c|c|c|c|c|c|}
\hline Time & Group & $\mathrm{E} 2, \mathrm{pg} / \mathrm{mL}$ & $\mathrm{P}, \mathrm{ng} / \mathrm{mL}$ & $\mathrm{LH}, \mathrm{mlU} / \mathrm{mL}$ & $\mathrm{FSH}, \mathrm{mlU} / \mathrm{mL}$ \\
\hline \multirow[t]{4}{*}{ 5th week(27 weeks old, $n=6)$} & Control & $682.26 \pm 160.43^{a}$ & $0.25 \pm 0.04^{a}$ & $3.54 \pm 0.60^{\mathrm{a}}$ & $2.48 \pm 0.55$ \\
\hline & 50 ppm SS & $782.42 \pm 166.81^{\mathrm{ab}}$ & $0.25 \pm 0.07^{a}$ & $4.63 \pm 0.95^{\mathrm{a}}$ & $2.85 \pm 0.53$ \\
\hline & 500 ppm SS & $928.54 \pm 133.90^{b}$ & $0.41 \pm 0.10^{b}$ & $8.76 \pm 1.68^{b}$ & $3.17 \pm 0.73$ \\
\hline & $P$-value & 0.026 & 0.001 & $<0.001$ & 0.132 \\
\hline \multirow[t]{4}{*}{ 10th week(32 weeks old, $n=8$ ) } & Control & $646.17 \pm 128.77^{\mathrm{ab}}$ & $0.23 \pm 0.08^{\mathrm{a}}$ & $5.11 \pm 1.74$ & $2.35 \pm 0.62^{\mathrm{a}}$ \\
\hline & 50 ppm SS & $701.59 \pm 98.47^{b}$ & $0.37 \pm 0.08^{b}$ & $5.76 \pm 1.16$ & $3.11 \pm 0.81^{b}$ \\
\hline & 500 ppm SS & $537.52 \pm 115.01^{\mathrm{a}}$ & $0.30 \pm 0.08^{\mathrm{ab}}$ & $4.38 \pm 1.43$ & $2.13 \pm 0.49^{\mathrm{a}}$ \\
\hline & $P$-value & 0.029 & 0.007 & 0.197 & 0.017 \\
\hline
\end{tabular}

At the end of the 5th and 10th week of the trial, 6-8 birds from each treatment were selected to obtain wing vein blood and harvest serum. The levels of E2, $\mathrm{P}$ $\mathrm{LH}$, and FSH in the serum were measured. The data in Table 6 different superscript letters indicate significant difference $(P<0.05)$; same superscript letters indicate no difference $(P>0.1)$, the same below 
between ileal bacteria and immune-related indicators at the end of the 5th week. At the end of the trial, the correlation between the indicators related to egg production performance, and the correlation between serum biochemical indicators and egg production performance were also analyzed by Pearson correlation analysis. All statistical analyses were performed by the SPSS 23.0 software (Chicago, IL, USA). Possibility values $<0.05$ were taken to indicate statistical significance. Graphpad prism 8.0 software was used to graph the data.

\section{Results}

Compared with the control group, the laying rate and the feed-to-egg ratio tended to be improved in the $50 \mathrm{SS}$ group $(0.05<P<0.1)$ (Fig. $1 C)$. It should be noticed that egg production rate of laying hens was significantly elevated from 2 nd to 4 th week $(P<0.05)$ (Fig. 1B). Unexpectedly, during the entire trial period, the egg production rate of 500 SS group was 3.6\% lower than that of Control group. With the supplementation of 50 $\mathrm{mg} / \mathrm{kg} \mathrm{SS}$, the ovarian mass and length index of laying hens at the end of the trial was raised (Tables 3 and 4). The quality of eggshells was improved in 50 and 500 SS group (Table 5).

With $50 \mathrm{mg} / \mathrm{kg}$ SS added, the serum FSH level was elevated at the end of the trial $(P<0.05)$ (Table 6). The contents of E2, P and LH in the serum were significantly elevated at the end of 5 th week in the 500 SS group $(P<0.05)$. However, the levels of E2 and LH in the serum were reduced numerically at the end of the trial. The mRNA levels of follicle stimulating hormone receptor (FSHR) in ovarian was up-regulated with $50 \mathrm{mg} / \mathrm{kg}$ SS supplementation $(P<0.01)$ (Fig. $2 \mathrm{~B})$. Interestingly, the mRNA levels of genes such as gonadotropin releasing hormone 1 (GnRH1) in hypothalamus and the estrogen related receptor $(E R R)$ were down-regulated in the 500 SS group $(P<0.01)$ (Fig. 2A, B). In order to further clarify, we conducted a correlation analysis of indicators related to egg production performance at the end of the trial. Results showed that some indicators such as the total oviducts length, shell gland length, the mRNA levels of ERR and FSHR in ovarian, and the mRNA level of GnRH1 in hypothalamus were highly positively correlated with egg production rate $(P<0.05)$ (Table 7$)$.

In addition to egg laying performance, we also explored the impact of SS on the immune function and the structure of intestinal flora. Results showed that at the end of 5th and 10th week, the peripheral blood LPS stimulation index and the proportion of $B$ lymphocytes were significantly increased in the 50 and 500 SS group (Fig. 3A, B, C, D). The antibody titer after 7 days of first immunization with BSA was elevated with 50 and $500 \mathrm{mg} / \mathrm{kg}$ SS addition. In addition, the antibody titer 7 days after the second immunization with BSA was raised with $500 \mathrm{mg} / \mathrm{kg}$ SS supplementation $(P<0.05)$ (Fig. $3 \mathrm{E})$. The contents of serum IgG and IgM were heightened in the 50 and 500 SS group at the end of trial $(P<0.05)$ (Table 8). The results of serum cytokines levels told us that the levels of IL-4 and IFN- $\gamma$ were elevated in the 50 and 500 SS group at the end of the trial $(P<0.05)$ (Table 9), however, the ratio of IFN- $\gamma$ to IL-4 was heightened with $500 \mathrm{mg} / \mathrm{kg} \mathrm{SS}$ supplementation $(P<0.05)$.

LEfSe analysis further showed that Lactobacillus delbrueckii was the dominant flora in the 50 SS group, and Lactobacillus_salivarius was regarded as the dominant flora in the 500 SS group (Fig. 4E). Compared with the control group, the relative abundance of Lactobacillus and Romboutsia (Fig. 5B) in the ileum chyme were elevated, and the relative abundance of Proteobacteria (Fig. $5 \mathrm{~A})$ was decreased in the 50 SS group. Clearly, the relative abundance of Lactobacillus salivarius was increased, and the relative abundance of Proteobacteria was reduced with $500 \mathrm{mg} / \mathrm{kg} \mathrm{SS}$ (Fig. 5A, 5C). The results of the correlation analysis between the bacteria and immune indicators at the end of 5th week showed that Firmicutes and Lactobacillus were positively correlated with the level of IL-4, IFN- $\gamma$ and the ratio of B cell in

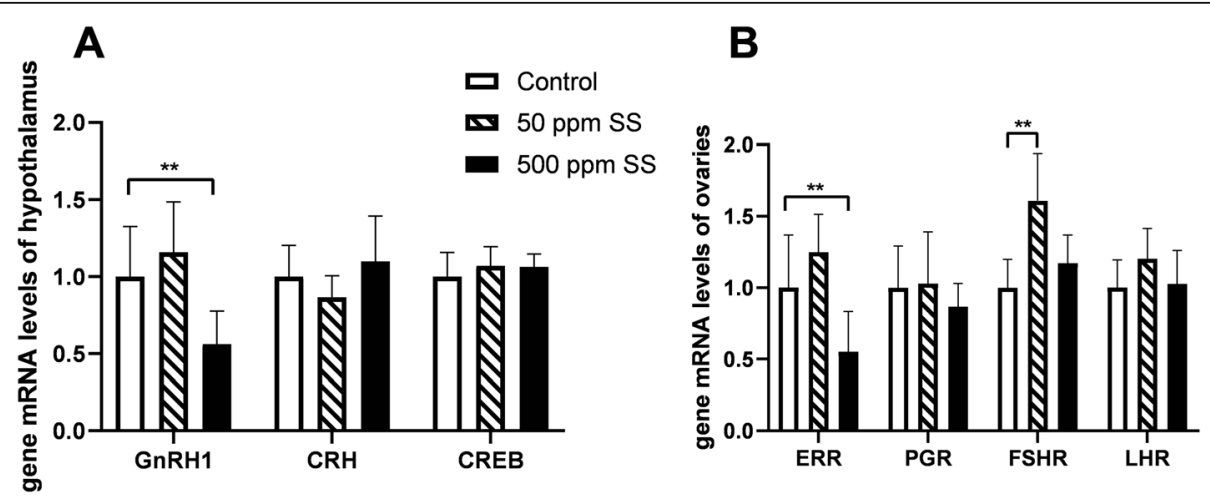

Fig. 2 The effect of SS on the gene mRNA levels about hypothalamus and ovary. The above $\mathbf{A}$ and $\mathbf{B}$ represented the results of gene mRNA levels about hypothalamus and ovary at the end of the trial. Among them, ${ }^{* *}$ represents an extremely significant difference $(P<0.01)$, the same below $(n=8)$ 
Table 7 Correlation analysis of related indexes about egg production performance at the end of the trial ( $^{*}$ represents $0.01<P<0.05$, ** represents $P<0.01$ )

\begin{tabular}{|c|c|c|c|c|c|c|c|c|c|c|c|c|c|c|c|}
\hline & E2 & $P$ & LH & FSH & $\begin{array}{l}\text { Egg- } \\
\text { laying } \\
\text { rate }\end{array}$ & $\begin{array}{l}\text { Ovaries } \\
\text { weight } \\
\%\end{array}$ & $\begin{array}{l}\text { Oviducts } \\
\text { weight } \\
\%\end{array}$ & $\begin{array}{l}\text { Total } \\
\text { oviducts } \\
\text { length }\end{array}$ & $\begin{array}{l}\text { Magnum } \\
\text { length }\end{array}$ & $\begin{array}{l}\text { Shell } \\
\text { gland } \\
\text { length }\end{array}$ & GnRH1 & ERR & $P G R$ & LHR & FSHR \\
\hline E2 & 1 & & & & & & & & & & & & & & \\
\hline P & 0.244 & 1 & & & & & & & & & & & & & \\
\hline $\mathrm{LH}$ & 0.005 & -0.120 & 1 & & & & & & & & & & & & \\
\hline FSH & 0.201 & 0.176 & $0.447^{*}$ & 1 & & & & & & & & & & & \\
\hline $\begin{array}{l}\text { Egg- } \\
\text { laying } \\
\text { rate }\end{array}$ & 0.153 & 0.251 & 0.170 & -0.082 & 1 & & & & & & & & & & \\
\hline $\begin{array}{l}\text { Ovaries } \\
\text { weight } \%\end{array}$ & 0.365 & 0.193 & 0.194 & 0.358 & 0.061 & 1 & & & & & & & & & \\
\hline $\begin{array}{l}\text { oviducts } \\
\text { weight } \%\end{array}$ & -0.003 & 0.048 & -0.093 & -0.040 & 0.167 & 0.198 & 1 & & & & & & & & \\
\hline $\begin{array}{l}\text { Total } \\
\text { oviducts } \\
\text { length }\end{array}$ & -0.110 & -0.101 & 0.096 & 0.009 & $0.488^{*}$ & 0.158 & $0.712^{* *}$ & 1 & & & & & & & \\
\hline $\begin{array}{l}\text { Magnum } \\
\text { length }\end{array}$ & -0.011 & 0.100 & 0.016 & 0.026 & 0.302 & 0.067 & $0.642^{* *}$ & $0.757^{* *}$ & 1 & & & & & & \\
\hline $\begin{array}{l}\text { Shell } \\
\text { gland } \\
\text { length }\end{array}$ & 0.330 & 0.111 & 0.182 & 0.283 & $0.786^{* *}$ & $0.424^{*}$ & 0.389 & $0.625^{* *}$ & 0.379 & 1 & & & & & \\
\hline GnRHI & $0.438^{*}$ & 0.051 & 0.153 & 0.212 & $0.482^{*}$ & 0.238 & 0.063 & 0.203 & 0.214 & 0.312 & 1 & & & & \\
\hline ERR & 0.283 & 0.095 & 0.166 & 0.171 & $0.672^{* *}$ & 0.358 & -0.046 & 0.316 & 0.303 & $0.454^{*}$ & $0.707^{* *}$ & 1 & & & \\
\hline$P G R$ & 0.235 & 0.020 & -0.094 & 0.069 & 0.035 & 0.026 & -0.185 & -0.045 & 0.069 & -0.061 & $0.474^{*}$ & $0.538^{* *}$ & 1 & & \\
\hline LHR & 0.332 & 0.217 & -0.009 & -0.002 & 0.316 & $0.509^{*}$ & 0.256 & 0.366 & 0.177 & 0.336 & 0.114 & 0.202 & 0.107 & 1 & \\
\hline FSHR & 0.274 & $0.518^{* *}$ & 0.186 & 0.311 & $0.524^{*}$ & 0.269 & 0.213 & 0.306 & 0.284 & $0.422^{*}$ & 0.305 & $0.451^{*}$ & $0.419^{*}$ & 0.320 & 1 \\
\hline
\end{tabular}

the blood $(P<0.05)$. Proteobacteria was significantly negatively correlated with the contents of IgM and the ratio of $\mathrm{B}$ cell in the blood $(P<0.05)$. Additionally, Lactobacillus delbrueckii was negatively correlated with the level of serum IL-2. Romboutsia was positively correlated with the level of IgG in serum $(P<0.05)$ (Fig. 6).

The results of mRNA levels in liver and spleen showed that $I L-4$ and $I F N-\gamma$ in liver, nuclear transcription factor kappa B $(N F-K B)$, interleukin-12 (IL-12), transforming growth factor $(T G F-\beta)$ and $I F N-\gamma$ in spleen were upregulated at the end of the trial in the $50 \mathrm{SS}$ group $(P<$ 0.05) (Figs. 7B, 8A, B). With $500 \mathrm{mg} / \mathrm{kg}$ SS supplemented, the gene mRNA levels of cysteinyl aspartate specific proteinase 1 (Caspase-1) in liver, $N F-\kappa B, I L-12$, Interleukin-1 $\beta(I L-1 \beta)$ and the ratio of $I F N-\gamma$ to $I L-4$ about spleen were up-regulated $(P<0.05)$. We also found that the levels of serum alanine aminotransferase (ALT) and alkaline phosphatase (ALP) were elevated in the 500 SS group (Table 10). Moreover, we observed from the liver tissue morphology that there was more immune cell infiltration of liver in the 500 SS group (Fig. 7C). Interestingly, the level of ALT and the ratio of IFN$\gamma$ to IL-4 in the serum were negatively correlated with the egg-laying rate (Fig. 9).

\section{Discussion}

In the present study, the egg production rate and FCR were improved with $50 \mathrm{mg} / \mathrm{kg}$ SS supplementation. It has been suggested that ginsenosides promotes the proliferation of ovarian cells in chicken [14-16], We could probably argue that SS might improve the development of the reproductive tract to regulate hormone secretion, thereby increasing the egg production rate. The physiological factors, especially endocrine factors regulate egg production via gonadotropin releasing hormone $(\mathrm{GnRH})$, estradiol (E2), prolactin (PRL), follicle stimulating hormone (FSH) and luteinizing hormone (LH). Importantly, the secretion of these hormones is controlled via the "hypothalamus-pituitary-ovarian" axis [24]. In the present study, the contents of E2 and FSH in the serum at 10th week were elevated with $50 \mathrm{mg} / \mathrm{kg} \mathrm{SS}$ addition. As a major estrogen produced in the ovaries, estradiol could promote the development of the reproductive system to improve the reproductive performance of the body. While FSH promotes the production of sperm in poultry or other vertebrates and stimulates the maturation of ovarian follicles $[25,26]$. Furthermore, a study showed that the ovarian FSH receptor (FSHR) stimulated the growth of follicles and regulates ovarian development via mediating estrogen synthesis 

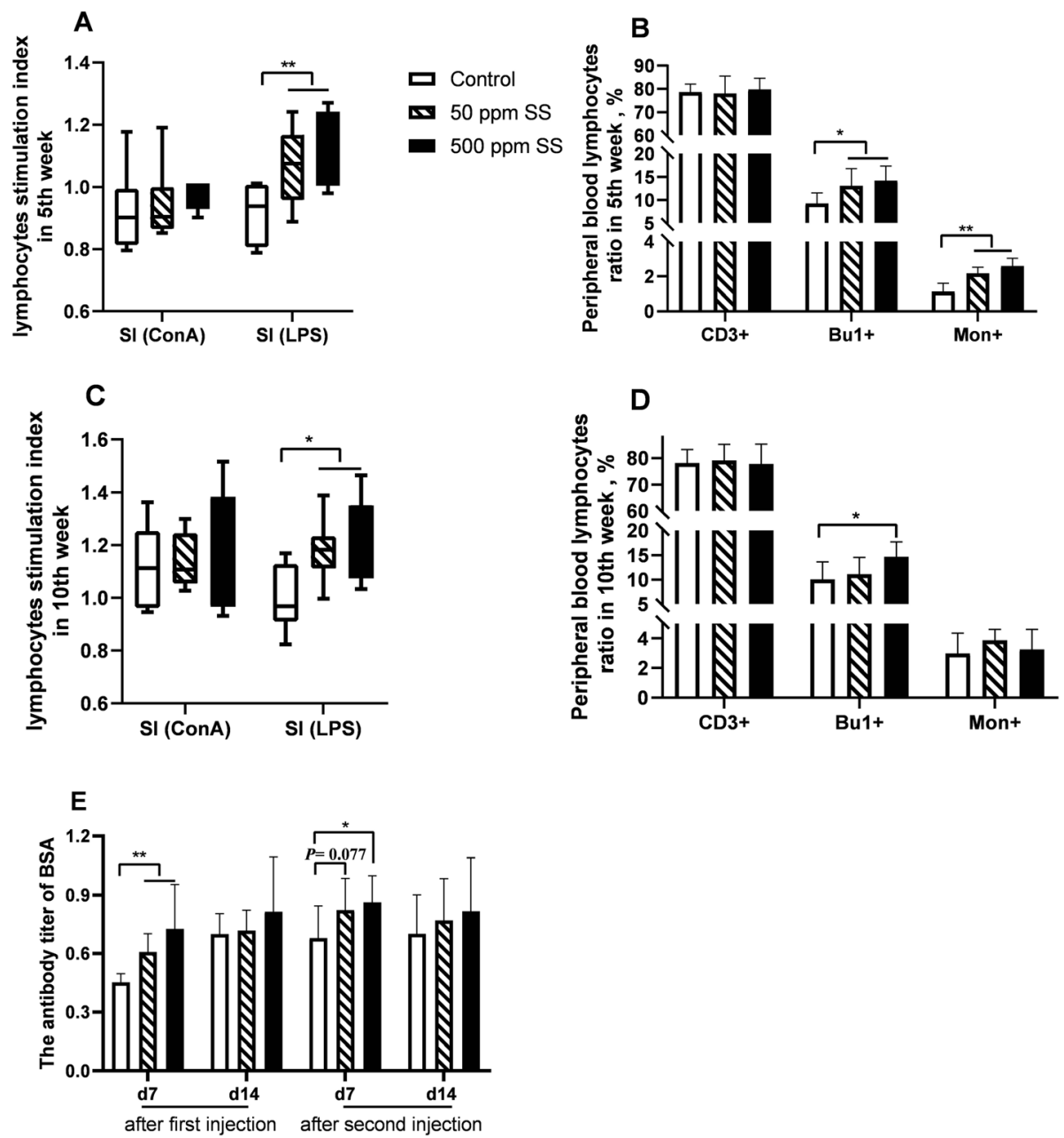

Fig. 3 The effects of SS on peripheral blood lymphocyte ratio, stimulation index, and the antibody titer of BSA. Peripheral blood lymphocyte stimulation index and lymphocyte ratio at the end of 5th week were showed in $\mathbf{A}$ and $\mathbf{B},(n=6)$. C and $\mathbf{D}$ showed the peripheral blood lymphocyte stimulation index and lymphocyte ratio at the end of $10^{\text {th }}$ week, $(n=8)$. The results of BSA antibody titer were showed in $\mathbf{E}$, $(n=8)$. Among them, ${ }^{* *}$ represents an extremely significant difference $(P<0.01)$, ${ }^{*}$ was judged as a significant difference $(0.01<P<0.05)$, the same below. Our analysis steps for flow cytometry results were as follows. At first, we use the CD45 ring gate to eliminate the interference of red blood cells. In the gate of $\mathrm{CD}^{+} 5^{+}$, T lymphocytes were labeled with $\mathrm{CD}^{+}$and their ratios were obtained. B lymphocytes and monocytes were labeled with $\mathrm{Bu}^{+}$and $\mathrm{Mon}^{+}$, and their ratios were obtained. The detailed flow analysis density map could be tracked in supplementary Figs. 1 and 2

Table 8 Serum immunoglobulin levels in 5th and 10th week

\begin{tabular}{llllll}
\hline & Item & Control & 50 ppm SS & 500 ppm SS & P-value \\
\hline 5th week(27 weeks old, $n=6)$ & $\mathrm{lgG}, \mathrm{ng} / \mathrm{mL}$ & $1156.99 \pm 52.49$ & $1149.89 \pm 35.00$ & $1142.72 \pm 46.55$ & 0.863 \\
& $\mathrm{lgA}, \mathrm{ng} / \mathrm{mL}$ & $296.73 \pm 14.41$ & $306.59 \pm 4.67$ & $309.71 \pm 5.80$ & 0.072 \\
& $\mathrm{lgM}, \mathrm{ng} / \mathrm{mL}$ & $86.33 \pm 14.59$ & $100.28 \pm 22.81$ & $98.09 \pm 15.22$ & 0.374 \\
10th week(32 weeks old, $n=8)$ & $\mathrm{lgG}, \mathrm{ng} / \mathrm{mL}$ & $1109.62 \pm 91.10^{\mathrm{a}}$ & $1262.94 \pm 92.65^{\mathrm{b}}$ & $1224.45 \pm 126.08^{\mathrm{b}}$ & 0.021 \\
& $\mathrm{lgA}, \mathrm{ng} / \mathrm{mL}$ & $294.04 \pm 12.71$ & $303.03 \pm 46.22$ & $307.40 \pm 32.11$ & 0.719 \\
& $\mathrm{lgM}, \mathrm{ng} / \mathrm{mL}$ & $70.11 \pm 10.80^{\mathrm{a}}$ & $94.08 \pm 11.95^{\mathrm{b}}$ & $85.87 \pm 16.77^{\mathrm{b}}$ & 0.006 \\
\hline
\end{tabular}

At the end of the 5th and 10th week of the trial, 6-8 birds from each treatment were selected to obtain wing vein blood and harvest serum. The levels of lgG, $\lg \mathrm{A}$, and $\lg \mathrm{M}$ in the serum were measured. The data in Table 8 different superscript letters indicate significant difference $(P<0.05)$; same superscript letters indicate no difference $(P>0.1)$, the same below 
Table 9 Serum cytokine levels in 5th and 10th week

\begin{tabular}{|c|c|c|c|c|c|}
\hline & Item & Control & $50 \mathrm{ppm} \mathrm{SS}$ & 500 ppm SS & $P$-value \\
\hline \multirow[t]{5}{*}{ 5th week(27 weeks old, $n=6$ ) } & $\mathrm{IL}-2, \mathrm{pg} / \mathrm{mL}$ & $72.05 \pm 4.25$ & $66.95 \pm 4.88$ & $70.11 \pm 4.92$ & 0.198 \\
\hline & $\mathrm{IL}-6, \mathrm{pg} / \mathrm{mL}$ & $83.24 \pm 9.76$ & $88.42 \pm 14.52$ & $91.17 \pm 18.16$ & 0.640 \\
\hline & $\mathrm{IL}-4, \mathrm{pg} / \mathrm{mL}$ & $20.08 \pm 2.83^{a}$ & $23.45 \pm 4.47^{\mathrm{ab}}$ & $29.87 \pm 8.57^{b}$ & 0.032 \\
\hline & IFN- $\gamma, \mathrm{pg} / \mathrm{mL}$ & $62.47 \pm 13.16$ & $67.01 \pm 10.64$ & $82.20 \pm 21.04$ & 0.104 \\
\hline & $\mathrm{IFN}-\gamma / \mathrm{IL}-4$ & $3.10 \pm 0.42$ & $2.93 \pm 0.60$ & $2.78 \pm 0.16$ & 0.450 \\
\hline \multirow[t]{5}{*}{ 10th week(32 weeks old, $n=8)$} & $\mathrm{IL}-2, \mathrm{pg} / \mathrm{mL}$ & $70.98 \pm 5.14$ & $73.56 \pm 8.82$ & $74.66 \pm 9.22$ & 0.643 \\
\hline & $\mathrm{IL}-6, \mathrm{pg} / \mathrm{mL}$ & $101.90 \pm 18.43$ & $111.58 \pm 25.05$ & $120.06 \pm 22.58$ & 0.283 \\
\hline & $\mathrm{IL}-4, \mathrm{pg} / \mathrm{mL}$ & $21.21 \pm 6.61^{\mathrm{a}}$ & $28.99 \pm 5.92^{b}$ & $26.02 \pm 4.35^{\mathrm{ab}}$ & 0.039 \\
\hline & $\mathrm{IFN}-\gamma, \mathrm{pg} / \mathrm{mL}$ & $55.04 \pm 14.61^{a}$ & $66.13 \pm 14.34^{\mathrm{ab}}$ & $78.17 \pm 12.35^{b}$ & 0.011 \\
\hline & $\mathrm{IFN}-\gamma / \mathrm{IL}-4$ & $2.63 \pm 0.24^{\mathrm{ab}}$ & $2.33 \pm 0.52^{\mathrm{a}}$ & $3.04 \pm 0.48^{b}$ & 0.012 \\
\hline
\end{tabular}

At the end of the 5th and 10th week of the trial, 6-8 birds from each treatment were selected to obtain wing vein blood and harvest serum. The levels of some cytokines in the serum were measured. The data in Table 9 different superscript letters indicate significant difference $(P<0.05)$; same superscript letters indicate no difference $(P>0.1)$, the same below

[27]. In the present study, the length of shell gland and the mRNA level of FSHR in the ovarian tissue were elevated with $50 \mathrm{mg} / \mathrm{kg}$ SS addition. We also found that the length of shell gland, the mRNA levels of ERR and FSHR in ovarian were highly positively correlated with egg production rate. It seems plausible that dietary $50 \mathrm{mg} / \mathrm{kg} \mathrm{SS}$ might improve egg production rate via improving the development of ovary and ovulation and stimulating the secretion of E2 and FSH.

This study showed that dietary $500 \mathrm{mg} / \mathrm{kg}$ SS significantly increased the level of E2, P, LH in the serum at the end of 5th week. Paradoxically, the content of E2 in the serum tended to decrease at the end of the trial. It has been reported that progesterone stimulates the pituitary gland to secrete FSH and LH to promote follicular maturation and ovulation. The increase in progesterone levels followed by higher levels of FSH and LH could be considered as an important indicator of ovarian function decline [28]. Likewise, E2 regulates ovarian activity through the feedback function of hypothalamus and pituitary. Decreased serum E2 level may cause ovarian dysfunction, premature ovarian failure and down's Syndrome $[29,30]$. A possible explanation could be that the high-dose SS in the early stage of the experiment excessively stimulated the laying hens to secrete P, E2 and $\mathrm{LH}$, which caused the ovarian function to decline. At the same time, the high-dose estrogen negative feedback regulated the "hypothalamus-pituitary-ovarian" axis. Thus, ovarian estrogen secretion was reduced. In the present study, the results of association analysis showed that the mRNA levels of ERR in ovarian, and GnRH1 in hypothalamus were highly positively correlated with egg production rate. we also found the mRNA levels of hypothalamus GnRH1 and ovary ERR were significantly down-regulated with $500 \mathrm{mg} / \mathrm{kg}$ SS supplemented at the end of trial. Although we did not observe a significant difference in egg production rates between control and the 50 SS groups, a 3.6\% reduction of egg production in 500 SS group is unacceptable for producers.

We observed a positive impact of SS supplementation on egg shell characteristic during the trial period. Past finding showed that $\mathrm{SS} \mathrm{Bb}$ promotes the absorption of zinc via increasing the expression of zinc transporter protein 4 (Zip4) protein in cells [31]. Also, SS promote the absorption and utilization of calcium via promoting the absorption and utilization of zinc [32]. This could explain why a positive impact of SS was observed in our study, as well.

Serum globulin level was used as an indicator to assess the innate immunity of animals [33]. In the present study, the serum globulin level was significantly elevated in the $50 \mathrm{SS}$ group at the end of the trial. Additionally, the proliferation and differentiation of peripheral blood lymphocytes directly determine immune function of the body. It is generally accepted that ConA promotes the proliferation of $\mathrm{T}$ cells, while LPS could directly stimulate the proliferation and differentiation of mature B cells [20]. It is commonly known that B cells are mainly involved in mediating fluid immune function, some researchers regarded the serum levels of total IgG, IgM and IgA as the basis for assessing the humoral immunity of poultry [34]. In our study, we also found that the stimulation index of LPS to peripheral blood lymphocytes and proportion of B lymphocytes were significantly raised with 50 and $500 \mathrm{mg} / \mathrm{kg}$ SS supplemented. It is tempting to believe that SS might improve the immune function by regulating the humoral immune response. Interestingly, we also found that the levels of serum IgG and IgM were raised with 50 and 500 $\mathrm{mg} / \mathrm{kg}$ SS addition. The serum levels of BSA antibody titer induced by intramuscular injection of BSA are regarded as the basis for assessing the humoral immunity of poultry [34]. In the present study, the antibody titer after 7 days of immunization with BSA was elevated with 50 and 500 $\mathrm{mg} / \mathrm{kg}$ SS addition. These evidences suggested that dietary 


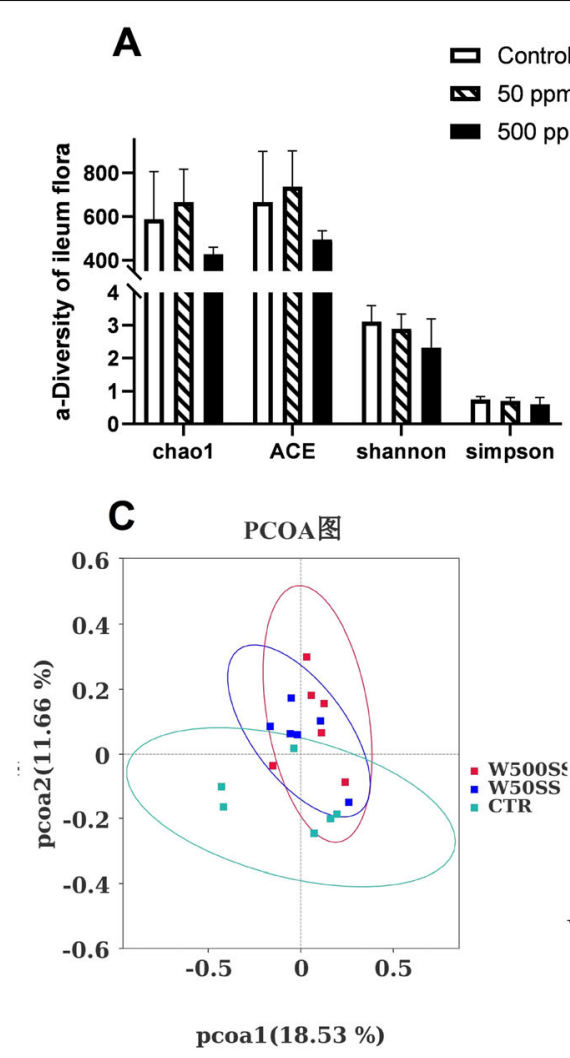

\section{B}
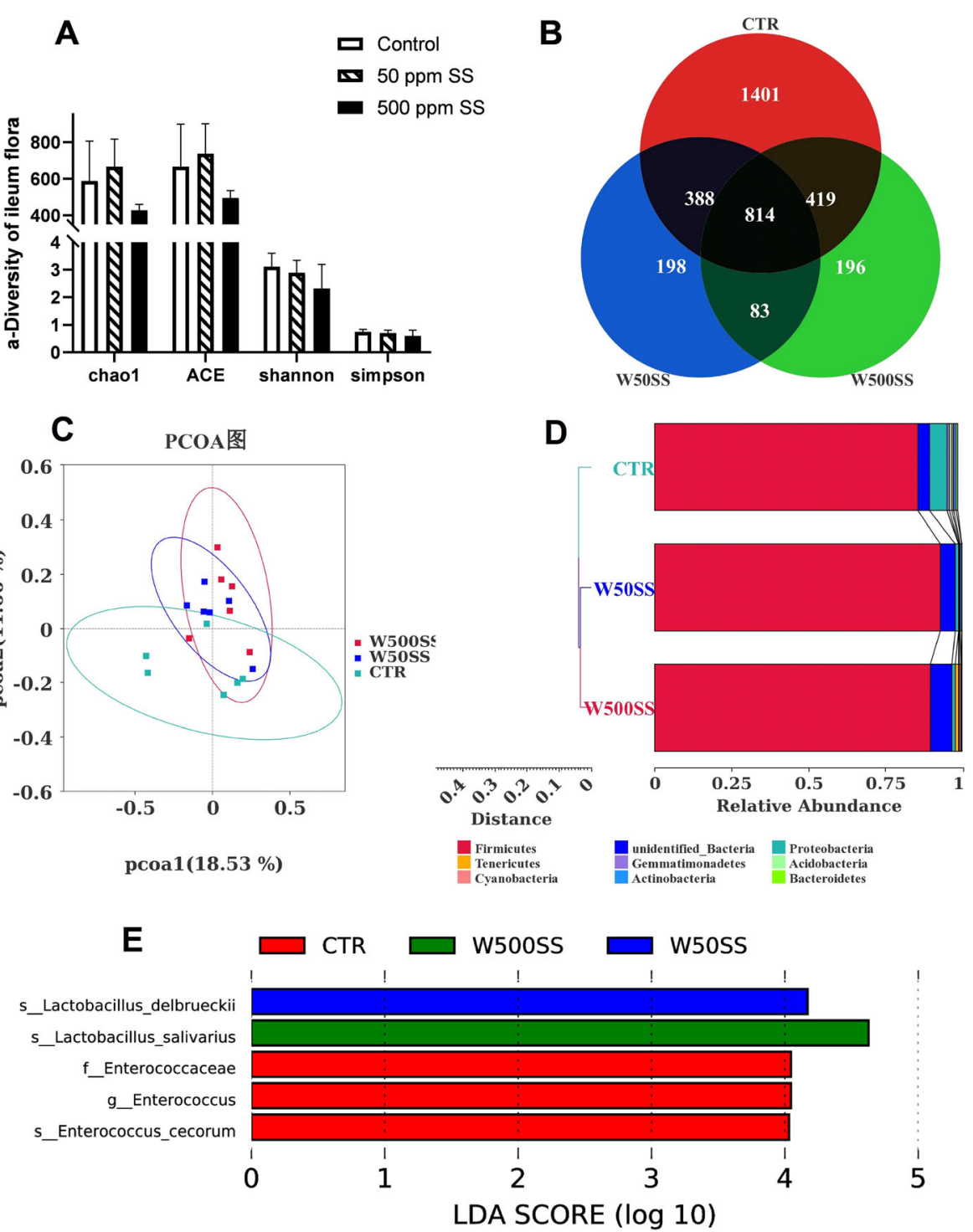

Fig. 4 The effect of SS on the microbial structure of the ileum of laying hens at the end of the 5 th week (27 week old). A, B, C, D, and E represented the a-diversity of the flora, the venn diagram of different species, the $\beta$-diversity (PCOA), the cluster structure of the flora, and the results of the differential flora analyzed by LEFSe. Among them, WCTR $=$ Control, WC50SS $=50$ ppm SS, WC500SS $=500$ ppm SS $(n=6)$

50 and $500 \mathrm{mg} / \mathrm{kg}$ SS might improve the immune function via regulating the humoral immune response of laying hens. It was basically consistent with the results reported by Naveed et al. [10].

Cytokines play an important role in regulating the immune function of the body. The coordinated expression of these pro-inflammatory and anti-inflammatory cytokines maintains the body's immune homeostasis [35, 36]. The typical representatives of pro-inflammatory and anti-inflammatory cytokines are IFN- $\gamma$ and IL-4, respectively. The ratio of IFN- $\gamma$ to IL-4 was used to reflect the immune homeostasis of body [37]. In the present study, the level of serum IL-4 was elevated in the 50 and 500 SS group at the end of 5th and 10th week. Study suggested that the expression of IL-4 stimulates the proliferation of B cells [35]. This might further prove that SS improved the humoral immune function of laying hens. To explain the observed activity, we might consider that the complex polysaccharide molecular structure of SS stimulated immune cells such as activated T cells to secrete cytokines, and the immune function of body was improved. Further research is needed to clearly understand this mechanism.

It is well established that the structure of the intestinal flora is closely related to the host's immune function. In the intestinal flora, bacteria of the genus Lactobacillus tend to metabolize to produce SCFAs and functional oligosaccharides, etc. These beneficial metabolites improve 


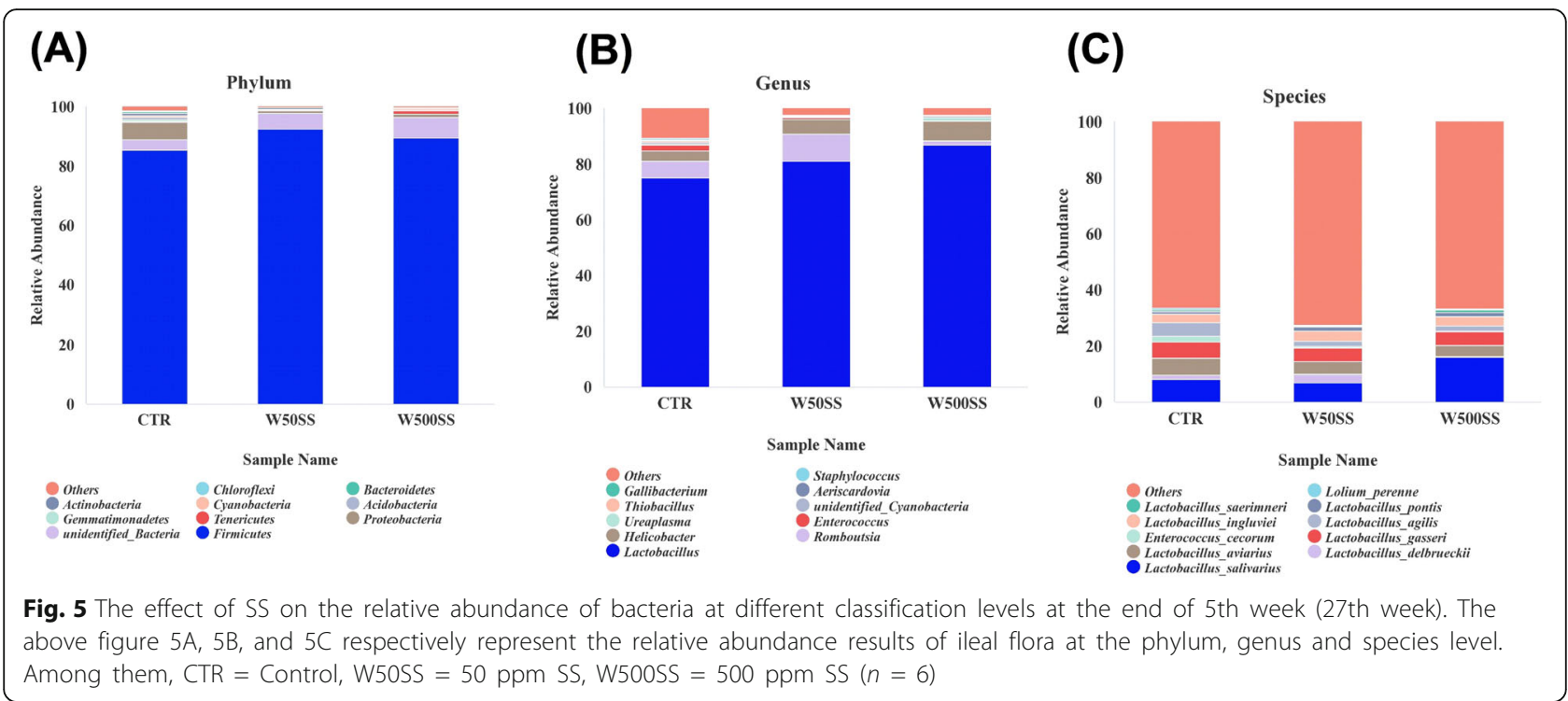

host immune function. However, some harmful bacteria, for instance pathogenic Escherichia coli, Campylobacter jejuni and Helicobacter pylori in the phylum Proteus metabolize and produce some endotoxins which affect the health of the host $[38,39]$. We found that the relative abundance of Lactobacillus in the ileal chyme was elevated, and the relative abundance of Proteobacteria was decreased in the 50 and 500 SS group. On the basis of these results, we concluded that an appropriate level of SS could improve the intestinal microflora of laying hens.

Romboutsia is a group of bacteria that ferment multiple carbohydrates and metabolize to produce SCFAs, oligosaccharides and other prebiotics. Studies found that Romboutsia was closely related to obesity, Crohn's disease and diabetes [40-42]. Romboutsia was also supposed to be the key role in regulating immune function [43]. Studies suggested that with the Lactobacillus delbrueckii supplemented, the immune function of Yellow River carp and mice were improved via elevating the level of serum lysozyme and IgM [44-46]. In the present study, the relative abundance of Romboutsia and Lactobacillus delbrueckii in ileal chyme were significantly heightened with $50 \mathrm{mg} / \mathrm{kg}$ SS supplemented. Studies also found that with Lactobacillus salivarius added to the diet of broiler, the antibody titer of the serum infectious bursal disease virus (IBDV) vaccine was increased, and the level of serum lysozyme was also elevated [35, 47]. In our study, the relative abundance of Lactobacillus salivarius in the ileal chyme was heightened in the 500 SS

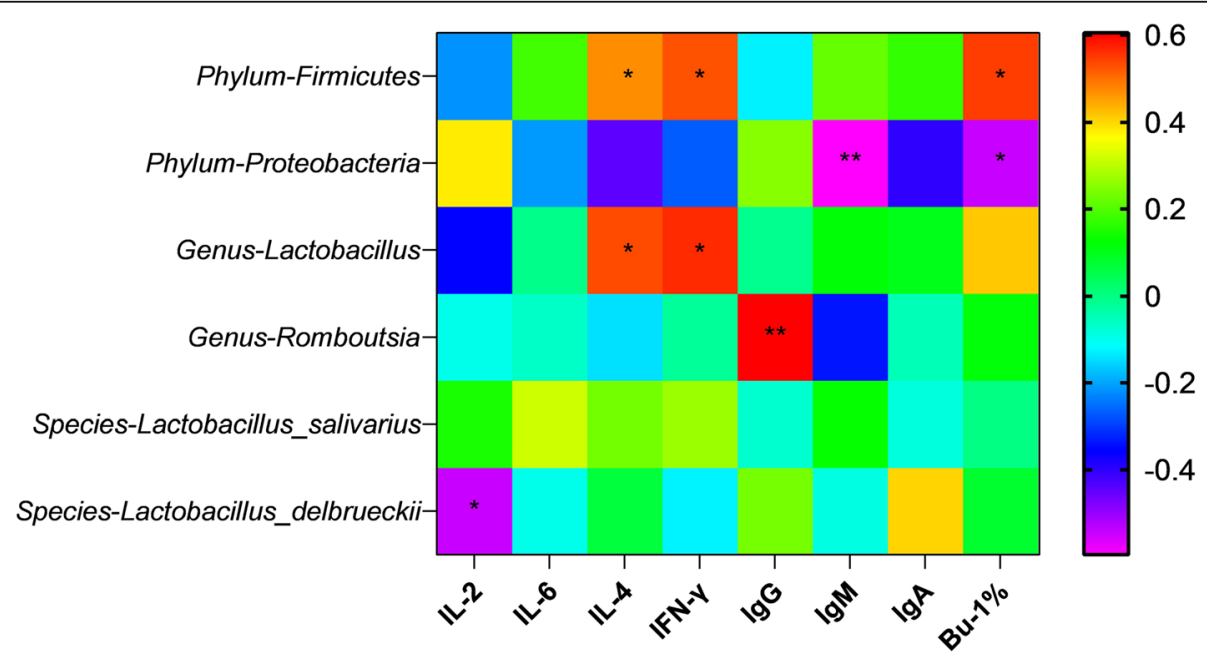

Fig. 6 The correlation analysis results between intestinal bacteria and immune-related indicators at the end of 5 th week (27 week old). The results of the correlation analysis between the immune-related indicators and the bacteria with differences at the end of 5th week were showed in Fig. 6. Among them, ${ }^{*}$ represents a significant difference $(0.01<P<0.05)$, and ${ }^{* *}$ represents an extremely significant difference $(P<0.01)$ 


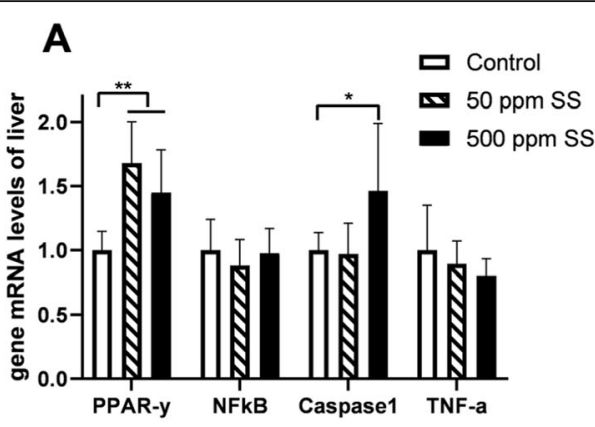

\section{B}

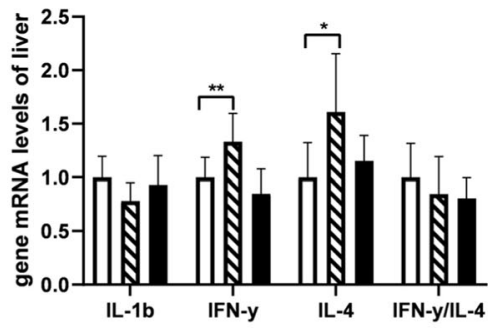

C

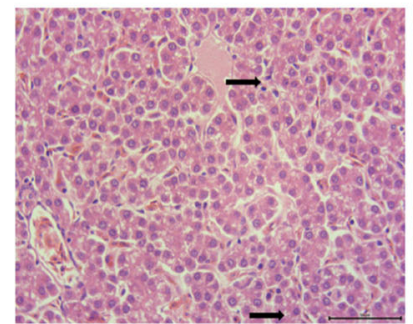

Control

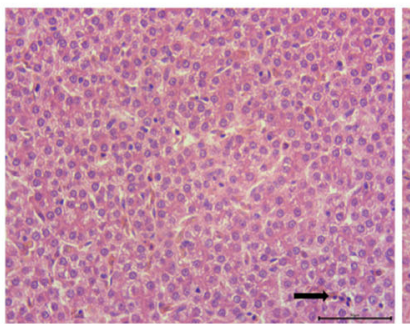

$50 \mathrm{ppm}$ SS

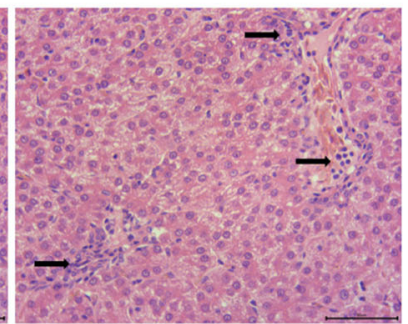

$500 \mathrm{ppm}$ SS

Fig. 7 The effect of SS on the gene mRNA levels and morphology of liver. The above $\mathbf{A}$ and $\mathbf{B}$ represented the results of gene mRNA levels about liver at the end of the trial. The morphological observation results about the liver at the end of the trial were showed in $\mathbf{C}$ above. The arrow points to the infiltration of immune cells. Among them, ** represents an extremely significant difference $(P<0.01)$, * was judged as a significant difference $(0.01<P<0.05)$, the same below $(n=8)$

group. We also found that Firmicutes and Lactobacillus were positively correlated with the levels of IL-4, IFN- $\gamma$, and the ratio of $\mathrm{B}$ cell in the blood. Proteobacteria was significantly negatively correlated with the contents of IgM and the ratio of B cell. Additionally, Romboutsia were positively correlated with the content of IgG in serum. It illustrated us that dietary 50 and $500 \mathrm{mg} / \mathrm{kg} \mathrm{SS}$ might improve the immune function via improving intestinal flora during the first 5 weeks of the trial. It should be mentioned that Romboutsia, Lactobacillus delbrueckii, and Lactobacillus salivarius might participate in the metabolic process of SS in the intestine, and then produce some biologically active substances to regulate immune function. Further research is needed to clearly understand this mechanism.

$\mathrm{NF}-\mathrm{kB}$ is the central regulator of cellular stress in all cell types of the body, it participates in the regulation of innate and adaptive immunity, as well as cell turnover [48]. Under non-pathological conditions, the body's immune system is activated by NF- $\mathrm{kB}$ to resist the stimulation of pathogens. However, once NF-kB is excessively activated, the overexpression of pro-inflammatory cytokines such as IL-1 $\beta$ and TNF- $\alpha$ lead body to an inflammatory response [49]. At the end of the trial, we found
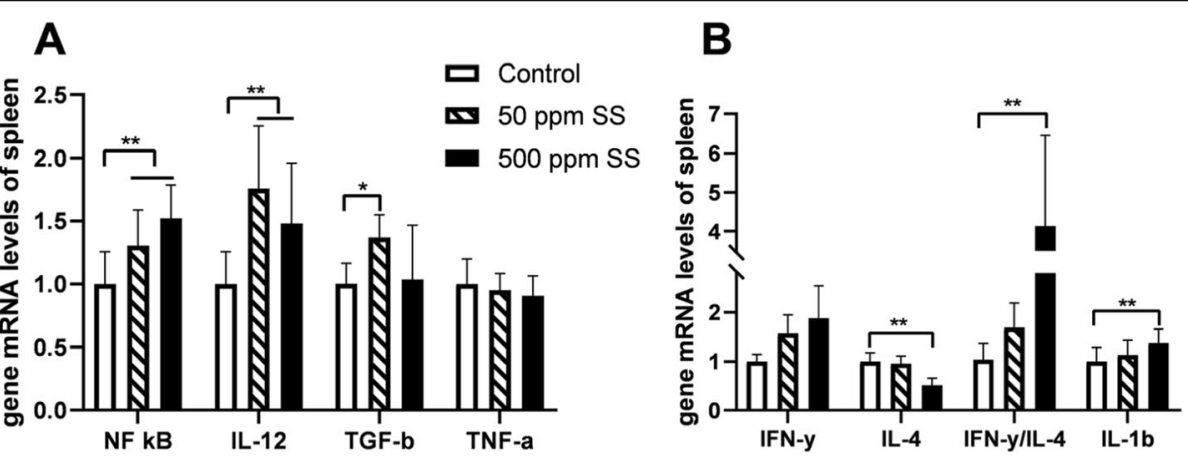

Fig. 8 The effect of SS on the gene mRNA levels of spleen. The results of gene mRNA levels about spleen at the end of the trial were showed in the above $\mathbf{A}$ and $\mathbf{B}$. Among them, ${ }^{* *}$ represents an extremely significant difference $(P<0.01)$, ${ }^{*}$ was judged as a significant difference $(0.01<P<$ 0.05), the same below $(n=8)$ 
Table 10 The results of serum biochemical index at the end of the trial $(n=8)$

\begin{tabular}{lllll}
\hline Item & Control & 50 ppm SS & 500 ppm SS & P-value \\
\hline TP, g/L & $32.63 \pm 1.27$ & $32.46 \pm 0.78$ & $32.47 \pm 0.76$ & 0.927 \\
ALB, g/L & $12.57 \pm 0.98$ & $11.88 \pm 0.88$ & $12.25 \pm 1.01$ & 0.377 \\
Globulin, g/L & $19.70 \pm 0.70^{\mathrm{a}}$ & $20.58 \pm 0.74^{\mathrm{b}}$ & $20.22 \pm 0.91^{\mathrm{ab}}$ & 0.106 \\
ALT, U/L & $14.02 \pm 1.55^{\mathrm{a}}$ & $13.44 \pm 1.54^{\mathrm{a}}$ & $15.56 \pm 1.07^{\mathrm{b}}$ & 0.019 \\
AST, U/L & $111.80 \pm 8.07$ & $111.70 \pm 8.12$ & $117.69 \pm 14.38$ & 0.447 \\
ALP, U/L & $313.08 \pm 21.85^{\mathrm{a}}$ & $369.94 \pm 13.68^{\mathrm{b}}$ & $379.88 \pm 28.54^{\mathrm{b}}$ & $<0.001$ \\
GLU, mmol/L & $12.15 \pm 0.15$ & $12.23 \pm 0.33$ & $12.19 \pm 0.50$ & 0.904 \\
\hline
\end{tabular}

At the end of the trial, 8 birds from each treatment were selected to obtain wing vein blood and harvest serum. The levels of serum biochemical index were measured. The data in Table 10 different superscript letters indicate significant difference $(P<0.05)$; same superscript letters indicate no difference $(P>0.1)$, the same below

the mRNA levels of genes such as NF- $\kappa B, I L-12, T G F-\beta$, and IFN- $\gamma$ in spleen were up-regulated in the 50 SS group. Additionally, the levels of IFN- $\gamma$ and IL-4 in the serum were also heightened. We also found that the ratio of IFN- $\gamma$ and IL-4 was not different from that of the control group, it indicated that the body was in immune homeostasis [37]. Thus, we hold that the increase of those cytokines makes a hen more responsive to challenges. It lighted us that dietary $50 \mathrm{mg} / \mathrm{kg}$ SS for 10 weeks could improve the immune function of laying hens. Unexpectedly, one unanticipated finding was that the mRNA levels of $N F-\kappa B, I L-12, I F N-\gamma, I L-1 \beta$ and the ratio of $I F N-\gamma$ to $I L-4$ in spleen were up-regulated as well as the level of serum IFN- $\gamma$ in the 500 SS group. In addition, the transcription level of spleen $I L-4$ was down-regulated, and the ratio of IFN- $\gamma$ to IL-4 in serum tended to be elevated. We despondently believed that dietary $500 \mathrm{mg} / \mathrm{kg}$ SS for 10 weeks could break immune homeostasis. It might have a negative effect on laying hens. To gain more insight, the following test was studied.

Caspase 1 is involved in the proteolytic activation of IL-1 $\beta$ family cytokines. When the body is in a state of stress, Caspase 1 will be activated [50]. The levels of ALT and AST in the blood are often used as indicators to evaluate liver function [51]. In the present study, the mRNA level of Caspase1 in liver, and the contents of ALT and ALP in serum were significantly raised in the $500 \mathrm{SS}$ group. We also found more inflammatory cell infiltration in the liver of this group. Although we did not find obvious signs of inflammation, dietary $500 \mathrm{mg} / \mathrm{kg}$ SS did have a negative effect on the liver of laying hens. Additionally, the results of the correlation analysis showed that the level of ALT and the ratio of IFN- $\gamma$ to IL-4 in the serum were negatively correlated with the egg-laying rate. It illuminated us that the long-term load of organs would inevitably have a negative impact on production performance. As we found in our study, the

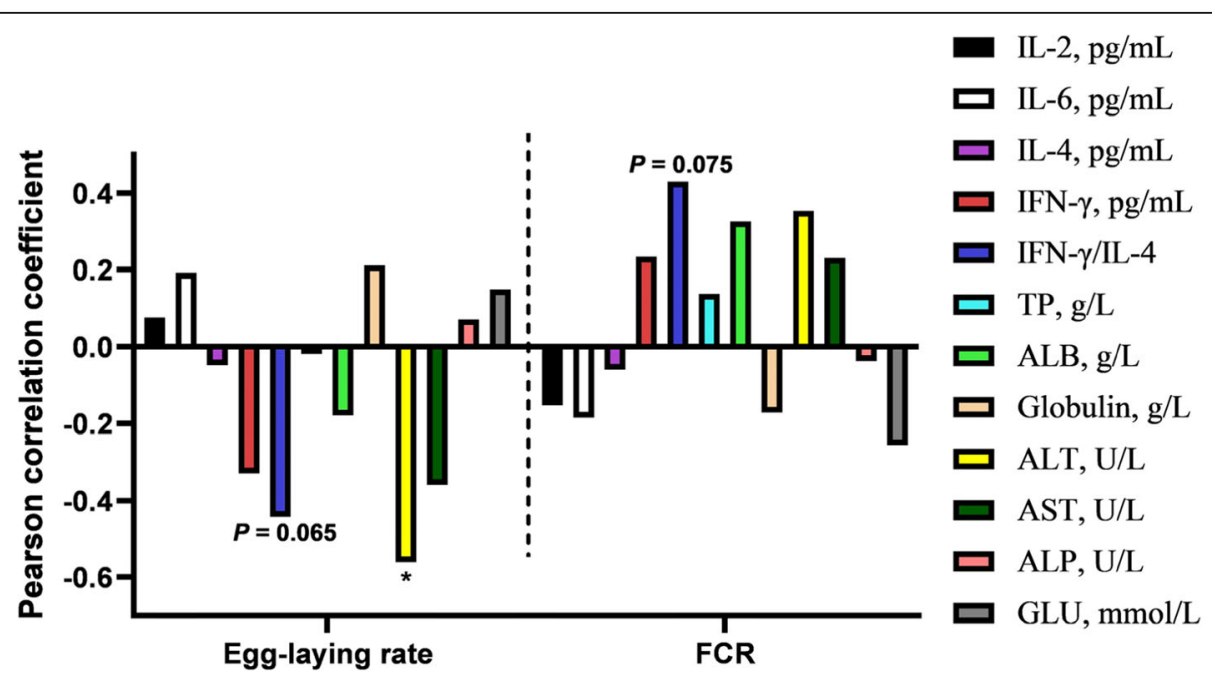

Fig. 9 Correlation analysis between serum biochemical indicators and egg production performance at the end of the trial. The results of correlation analysis between serum biochemical indicators and egg production performance at the end of the trial were showed in Fig. 9. Among them, * represents a significant difference $(0.01<P<0.05)$ 
egg production rate of 500 SS group was 3.6\% lower than that of Control group. To explain the observed activity, we might consider that a high dose of SS might stimulate the immune system for a period of time to improve the immune function. However, with prolonged immune stimulation response, the nutritional base of body will be consumed, and the organs would be overloaded. As a result, the production performance would be negatively affected.

\section{Conclusion}

Dietary $50 \mathrm{mg} / \mathrm{kg}$ SS improved the egg production performance via stimulating ovaries development, increasing ovarian FSHR transcription level and serum estrogen level. The intestinal microflora was regulated, and the immune function of laying hens also was improved with $50 \mathrm{mg} / \mathrm{kg}$ SS supplementation. The long-term supplementation of $500 \mathrm{mg} / \mathrm{kg}$ SS exerted a negative impact on the laying performance and physiological functions of the liver of laying hens.

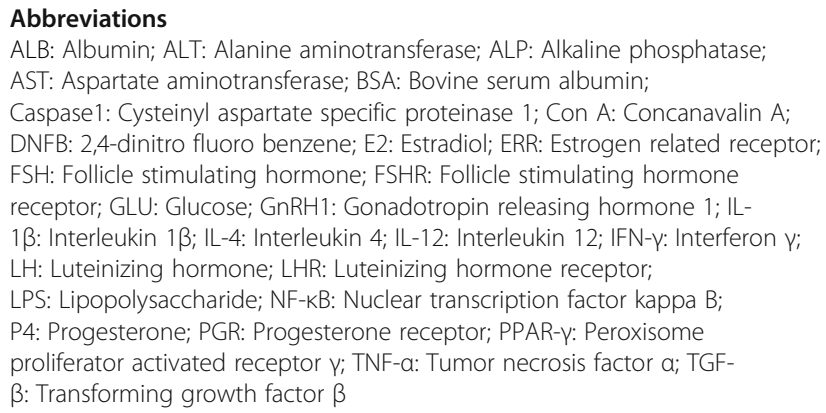

\section{Supplementary Information}

The online version contains supplementary material available at https://doi. org/10.1186/s40104-021-00647-2.

Additional file 1: Supplementary materials. The flow cytometry density map of peripheral blood at the end of 5th week (27 weeks old, $n=6$ ). Supplementary materials: the flow cytometry density map of peripheral blood at the end of 10th week (32 weeks old, $n=8$ ).

\section{Acknowledgements}

The authors acknowledge Dr. Tahir and American Journal Experts (http:// www.aje.com) for its linguistic assistance.

\section{Authors' contributions}

GY and LP designed the study, LP wrote the manuscript. LP, ZY, YS, SB, LY, TD collected and analyzed experimental results. GY participated in the writing and revision of the manuscript. All authors contributed to the data interpretation and approved the final version of the manuscript.

\section{Funding}

This project was funded by the China Agriculture Research System program (CARS-41-G11).

\section{Availability of data and materials}

The datasets produced and/or analyzed during the current study are available from the corresponding author on reasonable request.

\section{Declarations}

Ethics approval and consent to participate

All study procedures were approved by the Animal Care and Use Committee of China Agriculture University and were in accordance with the Beijing Guidelines for Experimental Animals established by the Ministry of Science and Technology (Beijing, China).

\section{Consent for publication}

Not applicable.

\section{Competing interests}

The authors declare that they have no competing interests.

Received: 10 June 2021 Accepted: 26 October 2021

Published online: 05 January 2022

\section{References}

1. Guang C, Chen J, Sang S, Cheng S. Biological functionality of soyasaponins and soyasapogenols. J Agric Food Chem. 2014;62(33):8247-55. https://doi. org/10.1021/jf503047a.

2. Lee I, Park Y, Yeo H, Han MJ, Kim D. Soyasaponin I attenuates TNBS-induced colitis in mice by inhibiting NF-KB pathway. J Agric Food Chem. 2010;58(20): 10929-34. https://doi.org/10.1021/jf102296y.

3. Zha L, Chen J, Sun S, Mao L, Chu X, Deng H, et al. Soyasaponins can blunt inflammation by inhibiting the reactive oxygen species-mediated activation of PI3K/Akt/NF-kB pathway. PLoS One. 2014;9(9):e107655. https://doi.org/1 0.1371/journal.pone.0107655

4. Yang SH, Ahn E, Lee JA, Shin T, Tsukamoto C, Suh J, et al. Soyasaponins aa and ab exert an anti-obesity effect in 3T3-L1 adipocytes through downregulation of PPARY. Phytother Res. 2015;29(2):281-7. https://doi.org/1 $0.1002 /$ ptr.5252.

5. MacDonald RS, Guo J, Copeland J, Browning JJ, Sleper D, Rottinghaus GE, et al. Environmental influences on isoflavones and saponins in soybeans and their role in colon cancer. J Nutr. 2005;135(5):1239-42. https://doi.org/1 $0.1093 / \mathrm{jn} / 135.5 .1239$

6. Choi C, Choi S, Kim H, Lee K, Kim S, Kim S, et al. Germinated soy germ with increased soyasaponin ab improves BMP-2-induced bone formation and protects against in vivo bone loss in osteoporosis. Sci Rep. 2018;8(1):12970. https://doi.org/10.1038/s41598-018-31118-w.

7. Kim SH, Yuk HJ, Ryu HW, Oh SR, Song DY, Lee KS, et al. Biofunctional soyasaponin $\mathrm{Bb}$ in peanut (Arachis hypogaea L.) sprouts enhances bone morphogenetic protein-2-dependent osteogenic differentiation via activation of runt-related transcription factor 2 in $\mathrm{C} 2 \mathrm{C} 12$ cells. Phytother Res. 2019;33:1490-500.

8. Neveling DP, Dicks LMT. Probiotics: an antibiotic replacement strategy for healthy broilers and productive rearing. Probiotics Antimicrob Proteins. 2021;13(1):1-11. https://doi.org/10.1007/s12602-020-09640-z.

9. Mangan M, Olhava EJ, Roush WR, Seidel HM, Glick GD, Latz E. Targeting the NLRP3 inflammasome in inflammatory diseases. Nat Rev Drug Discov. 2018; 17(8):588-606. https://doi.org/10.1038/nrd.2018.97.

10. Naveed G, Ehtisham-ul-Haque S, Khan I, Rahman SU, Anam S, Usman M, et al. Enhancement in humoral response against inactivated Newcastle disease vaccine in broiler chickens administered orally with plant-derived soyasaponin. Poult Sci. 2020;99(4):1921-7. https://doi.org/10.1016/j.psj.201 9.11.050.

11. Fussbroich D, Schubert R, Schneider P, Zielen S, Beermann C. Impact of soyasaponin I on TLR2 and TLR4 induced inflammation in the MUTZ-3cell model. Food Funct. 2015;6(3):1001-10. https://doi.org/10.1039/C4 FO01065E.

12. Horie H, Chiba A, Wada S. Inhibitory effect of soy saponins on the activity of $\beta$-lactamases, including New Delhi metallo- $\beta$-lactamase 1. J Food Sci Technol. 2018;55(5):1948-52. https://doi.org/10.1007/s13197-018-3091-4.

13. Yoo D, Kim D. Lactobacillus pentosus var. plantarum C29 increases the protective effect of soybean against scopolamine-induced memory impairment in mice. Int J Food Sci Nutr. 2015;66(8):912-8. https://doi.org/1 0.3109/09637486.2015.1064865.

14. Liu H, Zhang C, Tang X, Zeng W, Mi Y. Stimulating effects of androgen on proliferation of cultured ovarian germ cells through androgenic and estrogenic actions in embryonic chickens. Domest Anim Endocrinol. 2005; 28(4):451-62. https://doi.org/10.1016/j.domaniend.2005.02.018. 
15. Tan TQ, Ge C, Mi Y, Jin Y, Zhang C. Ginsenosides promote proliferation of granulosa cells from chicken prehierarchical follicles through PKC activation and up-regulated cyclin gene expression. Cell Biol Int. 2010;34(7):769-75. https://doi.org/10.1042/CBI20090244.

16. Yu WJ, Lee BJ, Nam SY, Yang DC, Yun YW. Modulating effects of Korean ginseng saponins on ovarian function in immature rats. Biol Pharm Bull. 2003;26(11):1574-80. https://doi.org/10.1248/bpb.26.1574.

17. He L, Ling L, Wei T, Wang Y, Xiong Z. Ginsenoside rg1 improves fertility and reduces ovarian pathological damages in premature ovarian failure model of mice. Exp Biol Med (Maywood). 2017;242(7):683-91. https://doi.org/10.11 77/1535370217693323.

18. Parmentier HK, Lammers A, Hoekman JJ, De Vries RG, Zaanen IT, Savelkoul HF. Different levels of natural antibodies in chickens divergently selected for specific antibody responses. Dev Comp Immunol. 2004;28(1):39-49. https:// doi.org/10.1016/S0145-305X(03)00087-9.

19. Fan H, Lv Z, Gan L, Guo Y. Transcriptomics-related mechanisms of supplementing laying broiler breeder hens with dietary daidzein to improve the immune function and growth performance of offspring. J Agric Food Chem. 2018;66(8):2049-60. https://doi.org/10.1021/acs.jafc.7b06069.

20. Wagner U, Burkhardt E, Failing K. Evaluation of canine lymphocyte proliferation: comparison of three different colorimetric methods with the 3H-thymidine incorporation assay. Vet Immunol Immunopathol. 1999;70(34):151-9. https://doi.org/10.1016/S0165-2427(99)00041-0.

21. Zhao D, Wu T, Yi D, Wang L, Li P, Zhang J, et al. Dietary supplementation with lactobacillus casei alleviates lipopolysaccharide-induced liver injury in a porcine model. Int J Mol Sci. 2017;18(12):2535. https://doi.org/10.3390/ijms1 8122535.

22. Fu WJ, Stromberg AJ, Viele K, Carroll RJ, Wu G. Statistics and bioinformatics in nutritional sciences: analysis of complex data in the era of systems biology. J Nutr Biochem. 2010;21(7):561-72. https://doi.org/10.1016/j. jnutbio.2009.11.007.

23. Zhang B, Lv Z, Li Z, Wang W, Li G, Guo Y. Dietary l-arginine supplementation alleviates the intestinal injury and modulates the gut microbiota in broiler chickens challenged by clostridium perfringens. Front Microbiol. 2018;9:1716. https://doi.org/10.3389/fmicb.2018.01716.

24. Du Y, Liu L, He Y, Dou T, Jia J, Ge C. Endocrine and genetic factors affecting egg laying performance in chickens: a review. Br Poult Sci. 2020;61(5):53849. https://doi.org/10.1080/00071668.2020.1758299.

25. Sharp PJ, Blache D. A neuroendocrine model for prolactin as the key mediator of seasonal breeding in birds under long- and short-day photoperiods. Can J Physiol Pharmacol. 2003;81(4):350-8. https://doi.org/1 0.1139/y03-025.

26. Tsutsui K, Bentley GE, Bedecarrats G, Osugi T, Ubuka T, Kriegsfeld LJ. Gonadotropin-inhibitory hormone $(\mathrm{G} n \mathrm{H})$ and its control of central and peripheral reproductive function. Front Neuroendocrinol. 2010;31(3):284-95. https://doi.org/10.1016/j.yfrne.2010.03.001.

27. Stilley JAW, Segaloff DL. FSH actions and pregnancy: looking beyond ovarian FSH receptors. Endocrinology. 2018;159(12):4033-42. https://doi. org/10.1210/en.2018-00497.

28. St CR. Estrogens and atherosclerosis: phytoestrogens and selective estrogen receptor modulators. Curr Opin Lipidol. 1998;9(5):457-63. https://doi.org/1 0.1097/00041433-199810000-00010.

29. Hsieh CY, Santell RC, Haslam SZ, Helferich WG. Estrogenic effects of genistein on the growth of estrogen receptor-positive human breast cancer (MCF-7) cells in vitro and in vivo. Cancer Res. 1998:58(17):3833-8.

30. Patel S, Homaei A, Raju AB, Meher BR. Estrogen: the necessary evil for human health, and ways to tame it. Biomed Pharmacother. 2018;102:40311. https://doi.org/10.1016/j.biopha.2018.03.078.

31. Hashimoto A, Ohkura K, Takahashi M, Kizu K, Narita H, Enomoto S, et al. Soybean extracts increase cell surface ZIP4 abundance and cellular zinc levels: a potential novel strategy to enhance zinc absorption by ZIP4 targeting. Biochem J. 2015;472(2):183-93. https://doi.org/10.1042/BJ20150862.

32. Müller JM, Ziegler-Heitbrock HW, Baeuerle PA. Nuclear factor kappa B, a mediator of lipopolysaccharide effects. Immunobiology. 1993;187(3-5):23356. https://doi.org/10.1016/S0171-2985(11)80342-6 .

33. Kim Y. Effect of a probiotic strain, enterococcus faecium, on the immune responses of olive flounder (paralichthys olivaceus). J Microbiol Biotechnol. 2012:22(4):526-9. https://doi.org/10.4014//mb.1108.08047.

34. Fairbrother A, Smits J, Grasman K. Avian immunotoxicology. J Toxicol Environ Health B Crit Rev. 2004;7(2):105-37. https://doi.org/10.1080/109374 00490258873
35. O'Garra A, Vieira P. T(H)1 cells control themselves by producing interleukin10. Nat Rev Immunol. 2007;7(6):425-8. https://doi.org/10.1038/nri2097.

36. Smith AJP, Humphries SE. Cytokine and cytokine receptor gene polymorphisms and their functionality. Cytokine Growth Factor Rev. 2009; 20(1):43-59. https://doi.org/10.1016/j.cytogfr.2008.11.006.

37. Koarada S, Wu Y, Olshansky G, Ridgway WM. Increased nonobese diabetic Th1:Th2 (ifn-gamma: il-4) ratio is $\mathrm{CD4}^{+} \mathrm{T}$ cell intrinsic and independent of APC genetic background. J Immunol. 2002;169(11):6580-7. https://doi.org/1 0.4049/jimmunol.169.11.6580.

38. Hiippala K, Jouhten H, Ronkainen A, Hartikainen A, Kainulainen V, Jalanka J, et al. The potential of gut commensals in reinforcing intestinal barrier function and alleviating inflammation. Nutrients. 2018;10(8):988. https://doi. org/10.3390/nu10080988

39. Lin Y, Xu S, Zeng D, Ni X, Zhou M, Zeng Y, et al. Disruption in the cecal microbiota of chickens challenged with clostridium perfringens and other factors was alleviated by bacillus licheniformis supplementation. PLoS One. 2017;12(8):e0182426. https://doi.org/10.1371/journal.pone.0182426.

40. Gao H, Jiang Q, Ji H, Ning J, Li C, Zheng H. Type 1 diabetes induces cognitive dysfunction in rats associated with alterations of the gut microbiome and metabolomes in serum and hippocampus. Biochim Biophys Acta Mol basis Dis. 2019;1865(12):165541. https://doi.org/10.1016/j. bbadis.2019.165541.

41. Russell JT, Roesch LFW, Ördberg M, llonen J, Atkinson MA, Schatz DA, et al. Genetic risk for autoimmunity is associated with distinct changes in the human gut microbiome. Nat Commun. 2019;10(1):3621. https://doi.org/10.1 038/s41467-019-11460- $x$

42. Zeng Q, Li D, He Y, Li Y, Yang Z, Zhao X, et al. Discrepant gut microbiota markers for the classification of obesity-related metabolic abnormalities. Sci Rep. 2019;9(1):13424. https://doi.org/10.1038/s41598-019-49462-w.

43. Min YN, Liu FX, Qi X, Ji S, Ma SX, Liu X, et al. Effects of methionine hydroxyl analog chelated zinc on laying performance, eggshell quality, eggshell mineral deposition, and activities of Zn-containing enzymes in aged laying hens. Poult Sci. 2018;97(10):3587-93. https://doi.org/10.3382/ps/pey203.

44. Barroso FAL, de Jesus LCL, de Castro CP, Batista VL, Ferreira Ê, Fernandes RS, et al. Intake of lactobacillus delbrueckii (pExu: hsp65) prevents the inflammation and the disorganization of the intestinal mucosa in a mouse model of mucositis. Microorganisms. 2021;9(1):107. https://doi.org/10.3390/ microorganisms 9010107

45. Li Y, Hou S, Peng W, Lin Q, Chen F, Yang L, et al. Oral administration of lactobacillus delbrueckii during the suckling phase improves antioxidant activities and immune responses after the weaning event in a piglet model. Oxidative Med Cell Longev. 2019;2019:6919803-10. https://doi.org/10.1155/2 019/6919803.

46. Zhang C, Zhang J, Guan W, Zhang X, Guan S, Zeng Q, et al. Effects of lactobacillus delbrueckii on immune response, disease resistance against aeromonas hydrophila, antioxidant capability and growth performance of cyprinus Carpio huanghe var. Fish Shellfish Immunol. 2017;68:84-91. https:// doi.org/10.1016/j.fsi.2017.07.012

47. Wang J, Ishfaq M, Guo Y, Chen C, Li J. Assessment of probiotic properties of lactobacillus salivarius isolated from chickens as feed additives. Front Vet Sci. 2020;7:415. https://doi.org/10.3389/fvets.2020.00415.

48. Yao J, Pan D, Zhao Y, Zhao L, Sun J, Wang Y, et al. Wogonin prevents lipopolysaccharide-induced acute lung injury and inflammation in mice via peroxisome proliferator-activated receptor gamma-mediated attenuation of the nuclear factor-kappa B pathway. Immunology. 2014;143(2):241-57. https://doi.org/10.1111/imm.12305.

49. Nagano T, Katase M, Tsumura K. Dietary soyasaponin attenuates 2,4dinitrofluorobenzene-induced contact hypersensitivity via gut microbiota in mice. Clin Exp Immunol. 2019;195(1):86-95. https://doi.org/10.1111/ cei.13212.

50. Mangifesta M, Mancabelli L, Milani C, Gaiani F, de Angelis N, de Angelis GL, et al. Mucosal microbiota of intestinal polyps reveals putative biomarkers of colorectal cancer. Sci Rep. 2018;8(1):13974. https://doi.org/10.1038/s41598-01 8-32413-2.

51. Collins TFX, Sprando RL, Black TN, Olejnik N, Eppley RM, Alam HZ, et al. Effects of zearalenone on in utero development in rats. Food Chem Toxicol. 2006;44(9):1455-65. https://doi.org/10.1016/j.fct.2006.04.015. 